\title{
Can a Non-Event Be an Event? The Case of Bank Stock Returns Surrounding Unexpected Interest Rate Inaction by the Federal Reserve
}

\author{
Allissa A. Lee \\ Georgia Southern University \\ David A. Carter \\ Oklahoma State University
}

\begin{abstract}
In September 2015, the Federal Open Markets Committee (FOMC) opted not to act when an increase in interest rates was largely expected. Further, President Yellen's comments were atypical. We investigate the effect of this announcement on the stock returns of US financial firms; more than a third of which experienced negative abnormal returns. The reaction; however, was not identical across firms indicating differential treatment based on individual firm characteristics. Our results suggest that institution size and classification as a commercial bank are the primary drivers. The outcomes of this study are important as they support the theory of rational pricing and market efficiency.
\end{abstract}

Keywords: interest rates, monetary policy, federal reserve, banks

\section{INTRODUCTION}

Rozeff (1975, p.18) states, "While few propositions about the stock market are universally accepted, most members of the financial community probably agree that changes in Federal Reserve Board monetary policy strongly influence changes in stock prices." Empirical research strongly supports this assertion. Chan and Gray (2018) further connect macroeconomic news and volatility, noting that bad news yields larger changes than good news.

The September 2015 meeting of the Federal Open Markets Committee (FOMC) of the Federal Reserve Bank (Fed) of the United States (U.S.) resulted in an unexpected interest rate announcement: the Fed elected to not raise interest rates. By all accounts, markets were expecting a slight increase in the federal funds rate in the September meeting. This would have been the first rise in interest rates in nearly a decade, ${ }^{1}$ and markets were primed and ready for the change - a signal that the Fed believed the economy had improved and was strong enough to support the interest rate increase. The announcement, at $2 \mathrm{pm}$ on September 17, that the Fed had determined it best to leave interest rates as-is was certainly unexpected and impacted the financial markets.

The press release by Janet Yellen, Fed President, suggests that weakness overseas and lower than expected inflation were contributing factors to the Fed's inaction. The Fed left room for increases to occur later in the year if improvement was observed. ${ }^{2}$ The statements by Yellen are part of what makes this 
analysis unique. In a University of Pennsylvania, Wharton Business Ratio Podcast, Peter Conti-Brown (2015) described

Yellen's citing turmoil in the international markets and "currency elements" such as the recent devaluation of the Chinese yuan as "relatively rare" considerations. In the normal course, Yellen would have attributed a decision on interest rates purely to price stability, or stable inflation, and maximum employment. "This time it was different and surprising." (para. 4).

Driebusch and Cox (2015) of The Wall Street Journal suggest that the Fed's decision is a reminder of U.S. reliance on, and vulnerability to, global issues, such as less than expected growth in China and weakness in other markets. They also note comments by QS Portfolio Manager Wayne Lin, who keyed in on the rarity of the Fed's announcement and stated, "What struck me about [the Fed's statement] was the reference to what was going on globally."

Bernanke and Kuttner (2005, p. 1225) state, "The market may, of course, also react to the lack of a change in the funds rate target, if a change has been anticipated." The purpose of this study is to explore the market reaction for financial institution equities to the Fed's decision not to increase interest rates. King (1966, p. 140) notes, "There is some news of a monetary nature, for example, which is bound to have a market-wide impact on security price. The magnitude of impact need not, however, be the same for all stocks." Banks largely stand to benefit from interest rate increases. For one, given that the savings rate is close to zero percent, banks were likely to increase lending rates while holding savings rates relatively constant. This would increase their spreads, improving net interest margins as well as profitability. This idea is consistent with findings of Hardouvelis (1987) who suggests that changes in monetary policy (altering the Federal Funds rate) affect financial firms to a greater extent since there is a direct impact to the cash flows of financial institutions.

Industry performance, measured with various Dow Jones Indices, on the day of the announcement and surrounding days suggest just such results (Table 1). More than half of the indices reported negative results on September 17, three of which were financially oriented. In fact, the U.S. Bank Index (DJUSBK) fared the worst, reporting a daily return more than 2 percent lower than the Dow Jones Industrial Average (DJIA). The Financial Services Index (DJUSFV) reported the second worst index return of about 1.35 percent lower than the DJIA.

\section{TABLE 1}

\section{DOW JONES INDEX PERFORMANCE - BY SECTOR}

\begin{tabular}{cccccccccc}
\hline Date & DJIA & DJTA & DJUSUT & DJUSFN & DJUSBK & DJUSFV & DJUSNC & DJUSEN & DJUSHC \\
\hline $\mathbf{9 / 1 6 / 2 0 1 5}$ & $0.84 \%$ & $0.24 \%$ & $1.15 \%$ & $0.66 \%$ & $0.50 \%$ & $0.60 \%$ & $1.51 \%$ & $2.89 \%$ & $0.25 \%$ \\
$\mathbf{9} / \mathbf{1 7} / \mathbf{2 0 1 5}$ & $-0.39 \%$ & $0.39 \%$ & $1.36 \%$ & $-1.00 \%$ & $-2.41 \%$ & $-1.73 \%$ & $0.08 \%$ & $-0.05 \%$ & $0.94 \%$ \\
$\mathbf{9 / 1 8} / \mathbf{2 0 1 5}$ & $-1.74 \%$ & $-2.18 \%$ & $-0.48 \%$ & $-1.76 \%$ & $-2.33 \%$ & $-2.23 \%$ & $-1.26 \%$ & $-2.72 \%$ & $-1.46 \%$ \\
\hline
\end{tabular}

This table presents daily returns for the day of (September 17, 2015) as well as the days prior to and following the Federal Reserve announcement. We obtain the data from S\&P Dow Jones Indices. The tickers and indices are as follows: DJIA (Dow Jones Industrial Average); DJTA (Dow Jones Transportation Average); DJUSUT (Dow Jones Utilities Index); DJUSFN (Dow Jones US Financials Index); DJUSBK (Dow Jones US Banks Index); DJUSFV (Dow Jones US Financial Services Index); DJUSNC (Dow Jones US Consumer Goods Index); DJUSEN (Dow Jones US Oil \& Gas Index); and DJUSHC (Dow Jones US Health Care Index).

Only a few studies (see, for example, Poole, Rasche, and Thornton 2002; and Bernanke and Kuttner 2005) explore the stock market reaction to a no change decision by the Fed. Opportunities to explore the relationship between interest rate changes, especially increases, and equity returns have been limited recently due to the fragility of the U.S. and global economies as a result of the Financial Crisis. Additionally, Kontonikas, MacDonald, and Saggu (2013, p. 4025) note "an important structural shift occurred during the crisis, changing the stocks' response to FFR [Federal Funds Rate] shocks." Given the uniqueness of Fed President Yellen's comments and the structural shift identified, this seems an 
opportune event to explore such associations and, in particular, for financial institutions. The results of this study should be of interest to policy makers, academics, and, certainly, the banking and investment communities.

In our analysis of the stock market reaction to the announcement of no change in the Fed Funds rate, we find that a significant number of firms experienced negative abnormal returns. Further, our results suggest that all firms were not universally affected by the Fed's announcement, which is to say that the reaction within the industry was not the same from firm-to-firm. Cross-sectional analysis reveals that individual firm size is the primary factor driving differential market reactions. We find that industry subsector classification matters as well.

This paper proceeds as follows: We provide a review of existing literature regarding interest rate announcements and the impact on equity prices and returns in the next section. Following that, we include a discussion of the data and empirical methodology utilized in this study. Finally, we report our empirical results and provide concluding remarks in the final two sections.

\section{LITERATURE REGARDING INTEREST RATES, EQUITY PRICES, AND RETURNS}

Much research exists examining the relationship between interest rates (monetary policy) and equity prices and how equities respond to changes in the rate. Smirlock and Yawitz (1985) document a statistical relationship between interest rate changes and the return on the New York Stock Exchange (NYSE) Index. Specifically, they note that, in the post-1979 era, exogenous increases in the discount rate result in negative returns on the NYSE Index. The relationship also holds for decreases in the discount rate that generate positive returns.

Hashemzadeh and Taylor (1988) examine the causality link between equity prices and interest rates. They document that the causality is only one-directional: from interest rates to stock prices. Alaganar and Bhar (2003), however, conclude just the opposite: that the causality is bi-directional.

Thorbecke and Alami (1994) document that when the Fed increases the Federal Funds target rate stock prices decline and vice versa. They imply that their results clearly identify a connection between monetary policy actions and stock prices. Jensen and Johnson (1995) also document a similar result but that the results are not symmetrical about a change. In fact, they note that returns are greater but less volatile when the Fed decreases rates compared to rate increases by the Fed. Similarly, Lobo (2002) finds that surprise decreases in the target rate result in substantial improvements in stock prices. He notes that the effect on stock price is not symmetrical with respect to surprise increases and decreases in rates and added "A test of these asymmetric effects across disclosure regimes revealed that [while] the type of interest rate surprise influenced mean changes in stock prices..." (p. 89).

Bae (1990) notes a strong negative association between unexpected interest rate changes and stock returns. Changes in the Federal Funds rate that are unanticipated result in larger changes in stock prices (Guo 2004; Basistha and Kurov 2008). Bernanke and Kuttner (2005) note a “...relatively strong and consistent response of the stock market to unexpected monetary policy actions..." (p. 1253) Their results suggest an increase in equity prices of about one percent given a 25 basis point reduction.

Tsai (2011) studies two types of surprise rate increases: those in which an increase occurs when the expectation is that the rate will be unchanged and also situations in which a rate decrease is expected but does not materialize. He finds that equities respond more to surprise increases in the target rate than they do to anticipated rate reductions that do not transpire. Likewise, Poole et al. (2002) find large revisions in investor expectations when an increase in the target rate was expected but the Fed failed to act.

Similarly, Huang, Mollick, and Nguyen (2016) examine stock market reaction to changes in the real interest rate. They include additional data (exchange rates and oil price) to proxy for global financial market conditions. In general, they find a negative correlation between stock prices and interest rates.

Existing literature attempts to document reasons for the differential responses. Guo (2004), Tsai (2011), and Kontonikas and Kostakis (2013) find size effects to be one of the contributing factors. Kontonikas and Kostakis (2013) additionally link asymmetrical responses to firm value and past performance. Further, monetary and economic conditions influence returns (Jensen, Mercer, and Johnson 
1996; Laopodis 2010) and the effect of other factors as well. For example, results of Guo (2004) suggest the size effect is prevalent during poor economic conditions but disappears when economic conditions improve.

Jensen, Mercer, and Johnson (1996) contend that the relationship is asymmetrical based on the monetary policy stance adopted by the Fed. When the Fed takes an expansionary attitude then stock returns are affected in a significant manner by monetary policy actions. Additionally, Basistha and Kurov (2008) acknowledge differences in equity price reactions to unexpected rate changes are due not only to recessionary market conditions and tight credit markets but also to the level of financial constraint of individual firms.

Connections exist between the business environment, monetary policy and returns on equity securities (Jensen and Mercer 2002). Specifically, they focus on investor expectations of the future and how the risk premiums change with expectations of future policy adjustments. According to conclusions made by Atanasov (2016), the asymmetric response of stock prices to monetary policy announcements results from conditional upside interest rate risk premiums which exceed conditional downside interest rate risk premiums.

As noted by King (1966), the reaction of equity prices to changes in interest rates does not have to be identical among industries or individual firms. Banks stand to gain the most from rate increases due to the positive influence on firm cash flows in most cases. Flannery and James (1984) identify a positive correlation between interest rates and bank stock prices. Hafer (1986) notes that the stock prices of utility companies as well as financial firms are impacted to a greater extent than other stocks to surprise changes in the interest rate. Similarly, Hardouvelis (1987) finds that “...among all stock price indexes, the NYSE Financial Index shows the strongest reactions to monetary news..." (p. 139)

The differential response of stock prices to interest rate changes among firms noted above, for equities in general, carries over to firms in the financial sector as well. Yin and Yang (2013) document that size, sources of income, and capital ratios impact individual firm responses to changes in the Federal Funds target rate. It is important to note that the data in the study terminate in 2007.

\section{DATA AND METHODOLOGY}

\section{Data and Sample}

We comprise our sample of daily stock prices for a selected set of publicly-traded financial institutions based in the U.S. to study the market reaction to the Fed's announcement. We obtain stock prices from CRSP for the period of June 30, 2014, through March 31, 2016, to calculate daily returns and collect accounting data from the FR Y-9C Holding Company Reports available from the Federal Reserve Bank of Chicago for December 2014. After eliminating firms with missing returns that are publicly traded, our final sample is 327 financial institutions. In Appendix Table 1A, we present descriptive information about each firm including measures of size, leverage, profitability, and interest rate risk.

Industry subsector classifications were determined according to the NAICS codes retrieved from CRSP for each firm and the 2012 NAICS definitions file available from the U.S. Census. We create industry subsector portfolios based on the individual firm NAICS Code. Most firms belong to one of three different subsectors: commercial banks, savings banks or bank holding companies; however, about 10 percent of the sample belongs to a variety of other subsectors, none of which are represented sufficiently to be stand-alone portfolios. As a result, we group these remaining firms into two broadly defined groups: (1) investment banks, security brokers/dealers and advisory services; and (2) other.

We calculate the GAP 12 Ratio as in Cyree, Huang, and Lindley (2012), which is the 12-month repricing gap, scaled by total assets. Also similar to Cyree et al. (2012), net interest margin (NIM) is defined as interest income less interest expense, scaled by earning assets. Leverage (D/E Ratio) is total liabilities divided by total shareholders' equity. Return-on-assets (ROA) is net income divided by total assets (TA). Size is defined as the natural logarithm of total assets and market capitalization (MKT Cap) is share price times the number of common shares outstanding. The market-to-book ratio (MB Ratio) is 
the market capitalization of the firm divided by the total book value of equity of the firm. We collect all market-based data from CRSP.

The firms that comprise our sample are large institutions with average total assets (market capitalization) of $\$ 45,385$ million ( $\$ 5,697$ million) with a range of $\$ 367$ million to $\$ 2,572,405$ million for total assets ( $\$ 7$ million to $\$ 284,386$ million for market capitalization). Net interest margin averages 0.020 (range: -1.034 to 0.098 ) and ROA ranges from -0.100 to 0.068 (mean: 0.008). For banks in particular, their inherent structure necessitates the use of leverage and oftentimes a significant degree of leverage. Our sample firms have leverage levels (debt-to-equity ratio) that range from 1.976 to 29.420 with an average debt-to-equity ratio of 8.260. Firms exhibit varying levels of interest rate risk exposure with an average GAP 12 ratio of 0.116 (range: -0.468 to 0.888 .)

\section{Empirical Methodology and Hypotheses}

We use multivariate regression model methodology as prescribed by Gibbons (1980) and Shipper and Thompson (1983). This methodology is often utilized when an event will affect all firms in an industry simultaneously and is an application of Zellner's (1962) SUR (seemingly unrelated regression) technique. This technique is appropriate due to the fact that the returns are likely correlated and the requirement that the residuals be identically and independently distributed is not met. Smirlock and Kaufold (1987) utilize this method to evaluate stock price reaction to the Mexican Debt Crisis, and Carter and Simkins (2004) apply this technique to study the effects of the September 11 Attacks on stock returns of airlines. For these reasons, this method is preferable to traditional event-study methodology prescribed by Brown and Warner (1985) and others. Accordingly, we estimate a system of linear equations for each firm in our sample for the sample period as follows:

$R_{i, t}=\alpha_{i}+\beta_{i} R_{M, t}+\gamma_{i} D_{t}+e_{i, t}$

where $R_{i, t}$ is the return of the stock on the $i^{t h}$ day, $R_{M, t}$ is the return on the Equally-Weighted CRSP Index on day $t$, and $D_{t}$ is a dummy variable taking the value of 1 on the event day (September 17,2015) and 0 otherwise. In Equation (1), we include the traditional market model, $\alpha i+\beta i R_{M t}$, plus $\gamma_{i} D_{t}$ that captures the excess return for each firm associated with the Fed's decision to not increase interest rates. We expect this term $\left(\gamma_{i}\right)$ to be negative, a priori.

We gauge the magnitude and significance of the market response to the Fed's decision using Equation (1) and test the following two hypotheses.

Hypothesis 1 (H1): $\gamma i=0$ for all i.

If we reject Hypothesis 1, then we surmise that the market views the Fed's decision not to increase interest rates as important to the value of individual firms (or portfolio) and consequently share price is affected. Existing literature finds a strong connection between Fed actions and equity prices as noted by numerous studies.

Hypothesis 2 (H2): $\gamma_{1}=\gamma_{2}=\ldots=\gamma_{n}$.

A rejection of Hypothesis 2 suggests that market reaction to the Fed's announcement was different for each firm (portfolio) and not identical across all firms (portfolios) in the industry and implies that the market believes the announcement will have varying effects on the different financial institutions. Monetary information can impact firms systematically; however, the extent of the effect does not have to be uniform across all stocks (King 1966).

\section{RESULTS}

We present our results in Tables 2A, 2, and 3. Table 2A reports the individual estimated abnormal returns for each firm. In Table 2 we present portfolio results. Finally, we utilize the abnormal returns 
estimated from Equation (1) as the dependent variables in cross-sectional regressions and report those results in Table 3.

\section{Tests of Hypotheses 1 and 2 (H1 and H2)}

An analysis of the results in Table 2A reveals that more than a third of firms (115 of 327) experienced negative abnormal returns on the day of the Fed's announcement. Of those firms that realized significant returns, the most negative abnormal return was -1.784 and the least negative abnormal return was -0.017 . Our analysis reveals no significant, positive abnormal returns. Accordingly, we perform a joint test of all firm's experiencing no abnormal return (abnormal return equal to zero), which we reject.

These results suggest a rejection of H1 implying that the market believed the Fed's decision to not increase interest rates will affect these firms. Additionally, we also report the results from the joint test that all firms experienced the same abnormal return (H2) attributable to the Fed's announcement. The result of that joint test supports a rejection of $\mathrm{H} 2$ and indicates that the returns are not uniform across all firms. As noted by Humphrey, Carter, and Simkins (2016), rejection of the hypothesis of equal market reaction among firms to an event supports the theory of rational pricing in the market and the absence of contagion. If contagion exists the market reaction would be uniform across all firms, regardless of the potential impact of the Fed's announcement on individual firms.

Bae (1990) notes differences in stock returns from unexpected interest rate changes based on industry subsectors and links the difference to asset-liability maturity imbalances as well as industry sensitivity to rate changes. Consequently, we examine industry-subsector portfolios and repeat the analysis as before. Our results, in Table 2, indicate significant abnormal returns for only one subsector: investment banks, security dealers/brokers, and advisory services. We reject $\mathrm{H} 1$ which is a joint test of all coefficients being equal to zero; however, we are unable to reject $\mathrm{H} 2$, which is a joint test of all coefficients being equal to one another.

At the individual firm level, our analysis suggests that the market differentiates between firms based on one or more firm-specific characteristics. The results for the industry subsector portfolios is less clear. Given the overwhelming support for rejection of $\mathrm{H} 1$ and $\mathrm{H} 2$ at the firm-level, that the market did not treat firms in a uniform manner, we analyze firm-specific characteristics in cross-sectional regressions to determine which factors contribute to the differential market reactions.

TABLE 2

\section{SHARE PRICE RESPONSE TO THE FED'S UNCHANGED INTEREST RATE ANNOUNCEMENT BY PORTFOLIO}

\begin{tabular}{|c|c|c|c|c|c|c|}
\hline Portfolio & \multicolumn{2}{|c|}{$\boldsymbol{\alpha} \mathbf{i}$} & \multicolumn{2}{|l|}{$\beta \mathbf{i}$} & \multicolumn{2}{|c|}{$\gamma \mathbf{i}$} \\
\hline Commercial Banks & -0.066 & $* * *$ & 1.085 & $* * *$ & 0.003 & \\
\hline Savings Banks & -0.112 & & 0.706 & & 0.032 & \\
\hline Bank Holding Companies & -0.114 & $* * *$ & 0.548 & & 0.014 & \\
\hline Investment Banks, Security Dealers/Brokers, Advisory Services & 0.000 & & 1.195 & $* * *$ & -0.022 & $* * *$ \\
\hline Other Finance & -0.110 & $* * *$ & 0.963 & $*$ & 0.101 & \\
\hline Joint test for all industry subsector portfolios & & & & & & \\
\hline $\mathrm{H} 1: \gamma_{1}=\gamma_{2}=\ldots=\gamma_{5}=0$ & & & & & 10.30 & $*$ \\
\hline Joint test for all industry subsector portfolios & & & & & & \\
\hline $\mathrm{H} 2: \gamma_{1}=\gamma_{2}=\ldots=\gamma_{5}$ & & & & & 2.53 & \\
\hline
\end{tabular}

In this table, we present the abnormal returns to industry subsector classification portfolios to the Fed's announcement that they were not increasing interest rates on September 17, 2015 estimated using Equation (1) as follows: $R_{i, t}=\alpha_{i}+\beta_{i} R_{M, t}+\gamma_{i} D_{t}+$ $e_{i, t}$. where $R_{i, t}$ is the return of the stock on the $i^{t h}$ day, $R_{M, t}$ is the return on the Equally-Weighted CRSP Index on day $t$, and $D_{t}$ is a dummy variable taking the value of 1 on the event day (September 17, 2015) and 0 otherwise. We calculate daily returns using security prices obtained from CRSP for the period of June 30, 2014 through March 31, 2016. We construct portfolio returns by averaging the daily returns of the firms in each respective portfolio. We determine industry subsector classifications according to reported NAICS codes obtained from CRSP. Significance is denoted by $* * *, * *$, and * at the $1 \%, 5 \%$, and $10 \%$ levels, respectively. 


\section{Cross-Sectional Results}

We utilize the abnormal returns obtained from estimating Equation (1) as our dependent variable and firm characteristics existing literature documents as important in the explanation of financial institution returns such as institution size, interest rate risk, and leverage as our independent variables (see definitions and data sources in the Data and Sample section) in cross-sectional regressions presented in Table 3. Industry subsectors, as defined in the Data and Sample Section, are dummy variables taking the value of 1 if the firm belongs to the referenced subsector and 0 otherwise. GSIB is a dummy variable taking the value of 1 for institutions designated as a Global Systematically Important Bank according to the Financial Stability Board (as of 2014) and 0 otherwise. This variable is included because institutions receiving the GSIB designation are required to maintain higher capital levels and are subject to additional regulatory and policy requirements (BIS, 2018).

We obtain cumulative abnormal returns (CARs) for various periods around the event day (Day 0: September 17, 2015) by summing the appropriate abnormal return estimates. We then substitute these into the cross-sectional regression equation as the dependent variable. In total, we include four additional sets of dependent variables including a two-day CAR $(0,+1)$, three-day CARs of $(0,+2)$ and $(-1,+1)$ and a five-day CAR $(-2,+2)$.

Our results resoundingly indicate size as the dominate factor the markets used to differentiate among firms in response to the Fed's announcement. Industry subsector classification matters as well with firms classified as commercial banks faring the worst, a result consistent with industry performance trends suggested in Table 1. Interestingly, our regression results do not suggest other factors including leverage, net interest margin, market-to-book ratio, profitability, and interest rate risk affect returns. These results suggest that large firms suffered more from the Fed's unexpected (in)action and respective commentary. It appears that the market believed these firms were likely to be impacted the most from the missed opportunity to increase interest rate spreads, and consequently profits.

TABLE 3 CROSS-SECTIONAL REGRESSIONS

\begin{tabular}{|c|c|c|c|c|c|c|c|c|c|c|}
\hline Dependent Variable $=$ & \multicolumn{2}{|c|}{ AR (0) } & \multicolumn{2}{|c|}{ CAR $(0,+1)$} & \multicolumn{2}{|c|}{ CAR $(0,+2)$} & \multicolumn{2}{|c|}{$\operatorname{CAR}(-1,+1)$} & \multicolumn{2}{|c|}{$\operatorname{CAR}(-2,+2)$} \\
\hline Leverage & -0.001 & & 0.006 & & 0.001 & & 0.011 & & 0.016 & \\
\hline$M B$ Ratio & -0.029 & & -0.097 & & -0.126 & & -0.115 & & -0.128 & \\
\hline Size & -0.025 & $*$ & -0.077 & $* * *$ & -0.107 & $* * *$ & -0.093 & $* *$ & -0.120 & $* *$ \\
\hline NIM & 0.141 & & 0.244 & & 0.424 & & 0.349 & & 0.669 & \\
\hline GAP 12 Ratio & -0.035 & & 0.076 & & 0.089 & & 0.006 & & -0.003 & \\
\hline$R O A$ & 0.293 & & 1.565 & & 2.103 & & 3.547 & & 5.474 & \\
\hline$G S I B$ & 0.120 & & 0.315 & & 0.454 & $*$ & 0.410 & & 0.567 & \\
\hline$B H C$ & -0.122 & & -0.153 & & -0.190 & & -0.239 & & -0.389 & \\
\hline$C M L \_B K$ & -0.114 & & -0.200 & $*$ & -0.299 & $* *$ & -0.337 & $* *$ & -0.609 & \\
\hline$S A V \bar{B} K$ & -0.111 & & -0.185 & & -0.271 & $*$ & -0.259 & & -0.393 & \\
\hline$I B \overline{A D} V$ & -0.096 & & -0.161 & & -0.243 & & -0.269 & & -0.485 & \\
\hline Constant & 0.727 & $* *$ & 1.995 & $* * *$ & 2.862 & $* * *$ & 2.444 & $* * *$ & 3.259 & $* * *$ \\
\hline $\mathrm{R}^{2}$ & 0.032 & & 0.078 & & 0.108 & & 0.078 & & 0.075 & \\
\hline $\mathrm{N}$ & 327 & & 327 & & 327 & & 327 & & 327 & \\
\hline
\end{tabular}

In this table, we present the cross-sectional regression estimates of various firm characteristics regressed on the abnormal return associated with the Fed's announcement estimated from Equation (1) as follows: $R_{i, t}=\alpha_{i}+\beta_{i} R_{M, t}+\gamma_{i} D_{t}+e_{i, t}$. where $R_{i, t}$ is the return of the stock on the $i^{t h}$ day, $R_{M, t}$ is the return on the Equally-Weighted CRSP Index on day $t$, and $D_{t}$ is a dummy variable taking the value of 1 on the event day (September 17, 2015) and 0 otherwise. We calculate daily returns using security prices obtained from CRSP for the period of June 30, 2014 through March 31, 2016. Further, we include four additional sets of dependent variables including a two-day CAR $(0,+1)$, three-day CARs of $(0,+2)$ and $(-1,+1)$ and a five-day CAR $(-2,+2)$. Variable definitions are available in the Data and Sample Section. Significance is denoted by ***,**, and * at the 1\%, 5\%, and $10 \%$ levels, respectively. 


\section{Robustness Measures}

Our analysis relies on the use of the Equally-Weighted CRSP Index (with dividends) as a measure of overall market reaction. We repeat the same analysis using the Value-Weighted CRSP Index (with dividends) as well as the S\&P 500 Index. In general, we find the results to be qualitatively similar and robust to these alternate model specifications. We omit the results for brevity, but they are available upon request.

\section{CONCLUSION}

It is widely accepted that changes in interest rates affect securities prices. Some research suggests, however, that the impacts are not necessarily the same for all stocks or all industries. To be certain, bank stocks were poised to be affected the most from a rate increase because the higher rate would directly impact their cash flows, in a positive fashion. In its September 2015 meeting, the FOMC opted not to act when an increase in rates was largely anticipated. Further, comments by the Fed President were atypical. The result: we observe declines in many major U.S. indices around the Fed's announcement on September 17. In fact, the NYSE Index (New York Stock Exchange) experienced a -0.207 percent drop in index level from the $16^{\text {th }}$ to $17^{\text {th }}$ of September and -1.801 percent from the $17^{\text {th }}$ to the $18^{\text {th }}$ of September with an overall decline of 2.004 percent from the $16^{\text {th }}$ to the $18^{\text {th }}$ of September. Comparatively, the NYSE Financial Index suffered more significant changes in index value of -0.770 percent, -2.011 percent, and 2.765 percent, respectively, and the S\&P Financial Index fared even worse ( -1.735 percent, -2.245 percent, and -3.941 percent, respectively), results consistent with findings of Hardouvelis (1987) and performance results of Dow Jones Indices in Table 1.

Obviously, overall markets responded quite negatively; however, we explore the impacts to the equity securities of financial industry firms compared to the market as a whole. In general, we find that a significant number of firms experienced negative abnormal returns that were not identical across the industry, which is to say that some firms were affected more than others. Cross-sectional analysis reveals that institution size as well as industry subsector classification as a commercial bank are the dominate factors driving the differential market reactions. With the first increase in interest rates in nearly a decade, firms were looking forward to increasing spreads. When the Fed's announcement dashed those hopes, the markets penalized firms they believed the news would most likely harm. The outcomes of this study are important as they support the theory of rational pricing and market efficiency as a result of news. Federal Reserve stances on interest rates largely reflect expectations about the future, so market participants will also find the outcomes of interest.

\section{END NOTES}

1. The last increase in the interest rate by the Federal Reserve was in June of 2006.

2. The Fed did raise interest rates by $0.25 \%$ in December 2015 . 


\section{REFERENCES}

Alaganar, V., \& Bhar, R. (2003). An international study of causality-in-variance: Interest rate and financial sector returns. Journal of Economics and Finance, 27(1), 39-55.

Atanasov, V. (2016). Conditional interest rate risk and the cross-section of excess stock returns. Review of Financial Economics, 30(1), 23-32.

Bank for International Settlements (BIS). (2018). Retrieved from https: www.bis.org

Bae, S. (1990). Interest rate changes and common stock returns of financial institutions: Revisited. Journal of Financial Research, 13(1), 71-79.

Basistha, A., \& Kurov, A. (2008). Macroeconomic cycles and the stock market's reaction to monetary policy. Journal of Banking and Finance, 32(12), 2606-2616.

Bernanke, B., \& Kuttner, K. (2005). What explains the stock market's reaction to Federal Reserve Policy? Journal of Finance, 60(3), 1221-1257.

Brown, S., \& Warner, J. (1985). Using daily stock returns: The case of event studies. Journal of Financial Economics, 14(1), 3-31.

Carter, D., \& Simkins, B. (2004). The market's reaction to unexpected, catastrophic events: The case of airline stock returns and the September $11^{\text {th }}$ attacks. Quarterly Review of Economics and Finance, 44(4), 539-558.

Chan, K., \& Gray, P. (2018). Volatility jumps and macroeconomic news announcements. Journal of Futures Markets, 38(8), 881-897.

Conti-Brown, P. (2015, September 21). What's behind the Fed's interest rate decision? Business Radio Podcasts North America, University of Pennsylvania, Wharton School of Business.

Cyree, K., Huang, P., \& Lindley, J. (2012). The economic consequences of banks' derivative use in good times and bad times. Journal of Financial Services Research, 41, 121-144.

Driebusch, C., \& Cox, J. (2015, September 18). Stocks fall sharply as Federal Reserve decision sparks growth concerns. The Wall Street Journal.

Flannery, M., \& James, C. (1984). The effect of interest rate changes on the common stock returns of financial institutions. Journal of Finance, 39(4), 1141-1153.

Gibbons, M. (1980). Econometric methods for testing a class of financial models-An application of the Nonlinear Multivariate Regression Model, Dissertation, University of Chicago.

Guo, H. (2004). Stock prices, firm size, and changes in the Federal Funds Rate target. Quarterly Review of Economics and Finance, 44(4), 487-507.

Hafer, R. (1986). The response of stock prices to changes in weekly money and the discount rate. Federal Reserve Bank of St. Louis, March, 5-14.

Hardouvelis, G. (1987). Macroeconomic information and stock prices. Journal of Economics and Business, 39(2), 131-140.

Hashemzadeh, N., \& Taylor, P. (1988). Stock prices, money supply, and interest rates: The question of causality. Applied Economics, 20(12), 1603-1611.

Huang, W., Mollick, A., \& Nguyen, K. (2016). U.S. stock markets and the role of real interest rates. Quarterly Review of Economics and Finance, 59, 231-242.

Humphrey, P., Carter, D., \& Simkins, B. (2016). The market's reaction to unexpected, catastrophic events: The case of oil and gas stock returns and the Gulf Oil Spill. Journal of Risk Finance, $17(1), 2-25$.

Jensen, G., \& Johnson, R. (1995). Discount rate changes and security returns in the U.S., 1962-1991. Journal of Banking and Finance, 19(1), 79-95.

Jensen, G., \& Mercer, J. (2002). Monetary policy and the cross-section of expected stock returns. Journal of Financial Research, 25(1), 125-139.

Jensen, G., Mercer, J. \& Johnson, R. (1996). Business conditions, monetary policy, and expected security returns. Journal of Financial Economics, 40(2), 213-237.

King, B. (1966). Market and industry factors in stock price behavior. Journal of Business, 39(1) Part 2, 139-190. 
Kontonikas, A., \& Kostakis, A. (2013). On monetary policy and stock market anomalies. Journal of Business, Finance and Accounting, 40(7-8), 1009-1042.

Kontonikas, A., MacDonald, R., \& Saggu, A. (2013). Stock market reaction to Fed Funds Rate surprises: State dependence and the financial crisis. Journal of Banking and Finance, 37(11), 4025-4037.

Laopodis, N. (2010). Dynamic linkages between monetary policy and the stock market. Review of Quantitative Finance and Accounting, 35, 271-293.

Lobo, B. (2002). Interest rate surprises and stock prices. Financial Review, 37, 73-92.

Poole, W., Rasche, R., \& Thornton, D. (2002). Market anticipation of monetary policy actions. Federal Reserve Bank of St. Louis, July/August, 65-93.

Rozeff, M. (1975). Money supply and the stock market: The demise of a leading indicator. Financial Analysts Journal, 31(5), 18-76.

Shipper, K., \& Thompson, R. (1983). The impact of merger-related regulations on the shareholders of acquiring firms. Journal of Accounting Research, 21(1), 184-221.

Smirlock, M., \& Kaufold, H. (1987). Bank foreign lending, mandatory disclosure rules, and the reaction of bank stock prices to the Mexican debt crisis. Journal of Business, 60(3), 347-364.

Smirlock, M., \& Yawitz, J. (1985). Asset returns, discount rate changes, and market efficiency. Journal of Finance, 40(4), 1141-1158.

S\&P Dow Jones Indices. (2019). Retrieved from https://www.us.spindices.com/

Thorbecke, W., \& Alami, T. (1994). The effect of changes in the Federal Funds Rate target on stock prices in the 1970s. Journal of Economics and Business, 46(1), 13-19.

Tsai, C. (2011). The reaction of stock returns to unexpected increases in the Federal Funds Rate target. Journal of Economics and Business, 63(2), 121-138.

Yin, H., \& Yang, J. (2013). Bank characteristics and stock reactions to Federal Funds Rate target changes. Applied Financial Economics, 23(23), 1755-1764.

Zellner, A. (1962). An efficient method of estimating seemingly unrelated regressions and tests for aggregation bias. Journal of the American Statistical Association, 57(298), 348-368. 


\section{APPENDIX A}

TABLE 1A

SELECTED FINANCIAL DATA FOR SAMPLE BANK AND FINANCIAL HOLDING FIRMS

\begin{tabular}{|c|c|c|c|c|c|c|c|c|}
\hline Firm & Ticker & ROA & GAP 12 & $\mathbf{D} / \mathbf{E}$ & MB & NIM & MKT Cap & TA \\
\hline \multicolumn{9}{|l|}{ Commercial Banks } \\
\hline Atlantic Coast Financial Corp & ACFC & 0.002 & 0.028 & 8.793 & 0.851 & 0.034 & 62 & 708 \\
\hline ACNB Corp & ACNB & 0.009 & 0.131 & 8.905 & 1.189 & 0.026 & 131 & 1090 \\
\hline Bank of America Corp & BAC & 0.002 & 0.365 & 7.653 & 0.773 & 0.004 & 188139 & 2106796 \\
\hline Banc of California Inc & BANC & 0.005 & -0.459 & 10.858 & 0.757 & 0.008 & 381 & 5972 \\
\hline BancFirst Corp & BANF & 0.010 & 0.403 & 9.791 & 1.613 & 0.016 & 983 & 6575 \\
\hline BBCN Bancorp Inc & $\mathrm{BBCN}$ & 0.012 & 0.159 & 7.089 & 1.296 & 0.038 & 1144 & 7140 \\
\hline BB \& T Corp & BBT & 0.012 & 0.222 & 6.648 & 1.147 & 0.014 & 28012 & 186814 \\
\hline BCB Bancorp Inc & $\mathrm{BCBP}$ & 0.006 & -0.123 & 11.732 & 0.963 & 0.049 & 98 & 1302 \\
\hline Bridge Bancorp Inc & BDGE & 0.006 & 0.140 & 12.060 & 1.778 & 0.031 & 312 & 2289 \\
\hline Bank of NY Mellon Corp & BK & 0.007 & 0.176 & 8.955 & 1.180 & -0.028 & 45670 & 385303 \\
\hline Bank South Carolina Corp & BKSC & 0.012 & 0.338 & 8.993 & 1.794 & 0.037 & 66 & 367 \\
\hline BSB Bancorp Inc MD & BLMT & 0.003 & 0.196 & 9.405 & 1.233 & 0.026 & 169 & 1426 \\
\hline Bank of Marin Bancorp & BMRC & 0.011 & 0.114 & 7.934 & 1.561 & 0.038 & 312 & 1787 \\
\hline Bank of Commerce Holdings & $\mathrm{BOCH}$ & 0.006 & 0.115 & 8.625 & 0.765 & 0.035 & 79 & 997 \\
\hline Bank of Hawaii Corp & BOH & 0.011 & 0.082 & 13.084 & 2.466 & 0.019 & 2602 & 14859 \\
\hline Popular Inc & BPOP & -0.009 & 0.253 & 6.757 & 0.826 & 0.042 & 3523 & 33097 \\
\hline Sierra Bancorp & BSRR & 0.009 & -0.382 & 7.751 & 1.285 & 0.026 & 240 & 1637 \\
\hline BancorpSouth Inc & BXS & 0.009 & 0.319 & 7.298 & 1.347 & 0.016 & 2163 & 13327 \\
\hline Citigroup Inc & $\mathrm{C}$ & 0.004 & 0.333 & 7.702 & 0.774 & 0.020 & 163926 & 1842181 \\
\hline Camden National Corp & $\mathrm{CAC}$ & 0.009 & 0.018 & 10.382 & 1.207 & 0.025 & 296 & 2790 \\
\hline Cathay General Bancorp & CATY & 0.012 & 0.057 & 6.185 & 1.274 & 0.036 & 2042 & 11517 \\
\hline Capital Bank Financial Corp & $\mathrm{CBF}$ & 0.007 & 0.158 & 5.427 & 0.760 & 0.039 & 808 & 6836 \\
\hline Commerce Bancshares Inc & CBSH & 0.011 & 0.330 & 9.288 & 1.795 & 0.008 & 4189 & 24015 \\
\hline Capital City Bank Group & CCBG & 0.004 & 0.422 & 8.593 & 0.995 & 0.013 & 271 & 2614 \\
\hline CNB Financial Corp PA & CCNE & 0.011 & 0.218 & 10.611 & 1.413 & 0.036 & 266 & 2189 \\
\hline C \& F Financial Corp & CFFI & 0.009 & 0.058 & 9.856 & 1.101 & 0.054 & 136 & 1339 \\
\hline Chemical Financial Corp & $\mathrm{CHFC}$ & 0.008 & 0.228 & 8.186 & 1.260 & 0.023 & 1004 & 7322 \\
\hline Chemung Financial Corp & CHMG & 0.005 & -0.001 & 10.409 & 0.958 & 0.024 & 128 & 1525 \\
\hline CIT Group Inc & CIT & 0.024 & 0.327 & 4.283 & 0.966 & -0.041 & 8752 & 47880 \\
\hline Comerica Inc & CMA & 0.009 & 0.644 & 8.382 & 1.137 & 0.014 & 8417 & 69452 \\
\hline Century Bancorp Inc & CNBKA & 0.006 & 0.229 & 17.826 & 0.749 & 0.020 & 144 & 3624 \\
\hline CommunityOne Bancorp & $\mathrm{COB}$ & 0.068 & -0.414 & 7.300 & 1.038 & 0.030 & 277 & 2216 \\
\hline Capital One Financial Corp & $\mathrm{COF}$ & 0.014 & 0.358 & 5.860 & 1.019 & 0.054 & 45895 & 309083 \\
\hline Columbia Banking System Inc & COLB & 0.010 & 0.203 & 5.986 & 1.291 & 0.030 & 1586 & 8580 \\
\hline Central Pacific Financial Corp & $\mathrm{CPF}$ & 0.008 & -0.005 & 7.543 & 1.359 & 0.025 & 772 & 4853 \\
\hline CenterState Banks Inc & CSFL & 0.003 & 0.166 & 7.347 & 1.193 & 0.036 & 540 & 3777 \\
\hline Customers Bancorp Inc & CUBI & 0.006 & 0.199 & 14.402 & 1.125 & 0.026 & 498 & 6825 \\
\hline CVB Financial Corp & CVBF & 0.014 & 0.040 & 7.402 & 1.932 & 0.031 & 1696 & 7378 \\
\hline Discover Financial Services & DFS & 0.028 & 0.505 & 6.466 & 2.667 & 0.076 & 29698 & 83126 \\
\hline Eagle Bancorp Montana Inc & EBMT & 0.005 & -0.042 & 9.279 & 0.781 & 0.020 & 43 & 560 \\
\hline Enterprise Financial Services Corp & EFSC & 0.008 & 0.415 & 9.361 & 1.237 & 0.037 & 391 & 3277 \\
\hline Eagle Bancorp Inc & EGBN & 0.010 & 0.133 & 7.451 & 1.724 & 0.035 & 1071 & 5249 \\
\hline Community Bankers Trust Corp & ESXB & 0.007 & -0.074 & 9.736 & 0.895 & 0.042 & 96 & 1156 \\
\hline Evans Bancorp Inc & EVBN & 0.010 & -0.429 & 7.719 & 1.049 & 0.031 & 102 & 847 \\
\hline Eastern VA Bankshares Inc & EVBS & 0.005 & 0.106 & 7.807 & 0.625 & 0.033 & 84 & 1183 \\
\hline EverBank Financial Corp & EVER & 0.007 & 0.062 & 11.370 & 1.342 & 0.020 & 2345 & 21618 \\
\hline East West Bancorp Inc & EWBC & 0.012 & 0.211 & 9.082 & 1.950 & 0.044 & 5558 & 28738 \\
\hline First Bancshares Inc MS & FBMS & 0.006 & -0.002 & 10.368 & 0.773 & 0.030 & 74 & 1094 \\
\hline First Bancorp NC & FBNC & 0.008 & -0.003 & 7.304 & 0.939 & 0.043 & 364 & 3220 \\
\hline First Connecticut Bancorp Inc MD & FBNK & 0.004 & 0.167 & 9.597 & 1.115 & 0.027 & 262 & 2486 \\
\hline First Bancorp P R & FBP & 0.031 & -0.073 & 6.614 & 0.748 & 0.047 & 1250 & 12728 \\
\hline Fauquier Bankshares Inc & FBSS & 0.008 & 0.208 & 9.992 & 1.248 & 0.026 & 69 & 606 \\
\hline
\end{tabular}




\begin{tabular}{|c|c|c|c|c|c|c|c|c|}
\hline Firm & Ticker & ROA & GAP 12 & $\mathbf{D} / \mathbf{E}$ & MB & NIM & MKT Cap & TA \\
\hline First Community Bancshares Inc & FCBC & 0.010 & 0.052 & 6.422 & 0.863 & 0.031 & 303 & 2608 \\
\hline First Commonwealth Financial Corp & FCF & 0.007 & -0.033 & 7.881 & 1.181 & 0.025 & 846 & 6360 \\
\hline First Citizens Bancshares Inc NC & FCNCA & 0.005 & 0.353 & 10.190 & 1.035 & 0.017 & 2782 & 30075 \\
\hline First Financial Bancorp Ohio & FFBC & 0.009 & 0.209 & 8.204 & 1.457 & 0.028 & 1142 & 7218 \\
\hline First Financial Bankshares Inc & FFIN & 0.015 & 0.058 & 7.581 & 2.810 & 0.024 & 1915 & 5848 \\
\hline Farmers Capital Bank Corp & FFKT & 0.009 & 0.300 & 9.308 & 1.009 & 0.027 & 174 & 1783 \\
\hline First Horizon National Corp & FHN & 0.009 & 0.546 & 8.909 & 1.233 & 0.007 & 3195 & 25674 \\
\hline Financial Institutions Inc & FISI & 0.010 & 0.008 & 10.052 & 1.270 & 0.028 & 355 & 3090 \\
\hline Fifth Third Bancorp & FITB & 0.011 & 0.450 & 7.855 & 1.072 & 0.015 & 16790 & 138706 \\
\hline First Long Island Corp & FLIC & 0.008 & 0.044 & 10.659 & 1.688 & 0.028 & 394 & 2721 \\
\hline First Midwest Bancorp DE & FMBI & 0.007 & 0.386 & 7.580 & 1.208 & 0.022 & 1329 & 9445 \\
\hline FirstMerit Corp & FMER & 0.010 & 0.211 & 7.789 & 1.102 & 0.028 & 3124 & 24910 \\
\hline Farmers National Banc Corp & FMNB & 0.008 & 0.174 & 8.202 & 1.244 & 0.024 & 154 & 1137 \\
\hline FNB Corp PA & FNB & 0.009 & 0.365 & 6.978 & 1.144 & 0.025 & 2312 & 16127 \\
\hline First Bancorp Inc ME & FNLC & 0.010 & 0.053 & 8.141 & 1.201 & 0.030 & 194 & 1477 \\
\hline Republic First Bancorp Inc & FRBK & 0.002 & -0.468 & 9.767 & 1.258 & 0.029 & 142 & 1215 \\
\hline First Merchants Corp & FRME & 0.010 & 0.283 & 7.014 & 1.179 & 0.029 & 857 & 5825 \\
\hline First South Bancorp Inc & FSBK & 0.004 & 0.088 & 10.018 & 0.950 & 0.026 & 76 & 886 \\
\hline Fulton Financial Corp PA & FULT & 0.009 & 0.289 & 7.556 & 1.107 & 0.027 & 2211 & 17083 \\
\hline First United Corp & FUNC & 0.004 & 0.119 & 11.223 & 0.489 & 0.028 & 53 & 1332 \\
\hline German American Bancorp Inc & GABC & 0.013 & 0.153 & 8.777 & 1.763 & 0.028 & 403 & 2237 \\
\hline Glacier Bancorp Inc & GBCI & 0.014 & 0.028 & 7.080 & 2.027 & 0.029 & 2083 & 8307 \\
\hline Guaranty Bancorp & GBNK & 0.006 & 0.165 & 9.268 & 1.446 & 0.030 & 299 & 2125 \\
\hline Guaranty Federal Bancshares Inc & GFED & 0.009 & -0.185 & 9.228 & 0.928 & 0.037 & 57 & 629 \\
\hline Great Southern Bancorp Inc & GSBC & 0.011 & 0.040 & 8.425 & 1.300 & 0.049 & 546 & 3956 \\
\hline Hanmi Financial Corp & HAFC & 0.012 & 0.053 & 8.340 & 1.535 & 0.025 & 696 & 4235 \\
\hline Huntington Bancshares Inc & HBAN & 0.010 & 0.343 & 9.477 & 1.349 & 0.018 & 8537 & 66298 \\
\hline Hancock Holding Co & HBHC & 0.008 & 0.241 & 7.394 & 0.999 & 0.026 & 2469 & 20752 \\
\hline Horizon Bancorp IN & HBNC & 0.009 & 0.356 & 9.683 & 1.239 & 0.027 & 241 & 2077 \\
\hline Heritage Oaks Bancorp & HEOP & 0.005 & 0.091 & 7.640 & 1.437 & 0.035 & 284 & 1710 \\
\hline HF Financial Corp & HFFC & 0.003 & 0.115 & 11.399 & 0.966 & 0.025 & 98 & 1263 \\
\hline HMN Financial Inc & HMNF & 0.013 & -0.388 & 6.593 & 0.729 & 0.024 & 55 & 577 \\
\hline Hampton Roads Bankshares Inc & HMPR & 0.005 & 0.034 & 9.069 & 1.451 & 0.026 & 287 & 1989 \\
\hline Home Bancshares Inc & HOMB & 0.015 & 0.038 & 6.292 & 2.140 & 0.045 & 2173 & 7403 \\
\hline Heritage Commerce Corp & HTBK & 0.008 & 0.313 & 7.772 & 1.269 & 0.035 & 234 & 1617 \\
\hline Heartland Financial USA Inc & HTLF & 0.007 & -0.200 & 11.195 & 1.011 & 0.028 & 502 & 6052 \\
\hline Independent Bank Corp MI & IBCP & 0.008 & 0.270 & 7.982 & 1.197 & 0.022 & 300 & 2249 \\
\hline IberiaBank Corp & IBKC & 0.007 & 0.321 & 7.505 & 1.171 & 0.023 & 2169 & 15759 \\
\hline International Bancshares Corp & IBOC & 0.013 & 0.011 & 6.708 & 1.115 & 0.020 & 1764 & 12197 \\
\hline Independent Bank Group Inc & IBTX & 0.007 & 0.060 & 6.641 & 1.230 & 0.035 & 665 & 4133 \\
\hline First Internet Bancorp & INBK & 0.004 & 0.006 & 9.028 & 0.768 & 0.026 & 74 & 971 \\
\hline Independent Bank Corp MA & INDB & 0.009 & 0.332 & 8.937 & 1.604 & 0.026 & 1027 & 6365 \\
\hline IF Bancorp Inc & IROQ & 0.006 & -0.168 & 5.567 & 0.876 & 0.031 & 73 & 550 \\
\hline JP Morgan Chase \& Co & JPM & 0.008 & 0.366 & 10.079 & 1.007 & 0.000 & 233936 & 2572773 \\
\hline KeyCorp & KEY & 0.010 & 0.425 & 7.905 & 1.142 & 0.009 & 12042 & 93882 \\
\hline Lakeland Bancorp Inc & LBAI & 0.009 & 0.117 & 8.325 & 1.169 & 0.032 & 444 & 3538 \\
\hline LCNB Corp & LCNB & 0.009 & 0.002 & 7.816 & 1.116 & 0.030 & 140 & 1108 \\
\hline Fidelity Southern Corp & LION & 0.010 & 0.047 & 10.647 & 1.299 & 0.002 & 344 & 3086 \\
\hline Lakeland Financial Corp & LKFN & 0.013 & -0.080 & 8.529 & 1.981 & 0.027 & 716 & 3444 \\
\hline Middleburg Financial Corp & MBRG & 0.006 & 0.086 & 9.021 & 1.053 & 0.025 & 128 & 1223 \\
\hline MBT Financial Corp & MBTF & 0.006 & 0.116 & 8.504 & 0.843 & 0.021 & 113 & 1279 \\
\hline Merchants Bancshares Inc & MBVT & 0.007 & 0.328 & 12.696 & 1.540 & 0.023 & 194 & 1723 \\
\hline Mercantile Bank Corp & MBWM & 0.006 & -0.218 & 7.818 & 1.088 & 0.030 & 357 & 2893 \\
\hline Macatawa Bank Corp & $\mathrm{MCBC}$ & 0.007 & -0.243 & 10.113 & 1.293 & 0.021 & 184 & 1584 \\
\hline MutualFirst Financial Inc & MFSF & 0.008 & 0.035 & 10.167 & 1.241 & 0.029 & 158 & 1424 \\
\hline Monarch Financial Holdings Inc & MNRK & 0.011 & 0.412 & 8.920 & 1.362 & -0.024 & 146 & 1067 \\
\hline MidWestOne Financial Group Inc & MOFG & 0.010 & -0.349 & 8.341 & 1.249 & 0.030 & 241 & 1800 \\
\hline MainSource Financial Group Inc & MSFG & 0.009 & 0.032 & 7.709 & 1.258 & 0.021 & 454 & 3141 \\
\hline
\end{tabular}




\begin{tabular}{|c|c|c|c|c|c|c|c|c|}
\hline Firm & Ticker & ROA & GAP 12 & $\mathbf{D} / \mathbf{E}$ & MB & NIM & MKT Cap & TA \\
\hline MidSouth Bancorp Inc & MSL & 0.010 & 0.116 & 8.266 & 0.941 & 0.034 & 197 & 1937 \\
\hline M \& T Bank Corp & MTB & 0.011 & 0.466 & 6.838 & 1.345 & 0.014 & 16596 & 96687 \\
\hline National Bank Holdings Corp & NBHC & 0.002 & 0.032 & 5.066 & 0.951 & 0.039 & 755 & 4820 \\
\hline Northeast Bancorp & NBN & 0.005 & 0.186 & 6.303 & 0.779 & 0.047 & 86 & 810 \\
\hline NBT Bancorp Inc & NBTB & 0.010 & 0.059 & 8.023 & 1.334 & 0.021 & 1153 & 7798 \\
\hline National Bankshares Inc & NKSH & 0.015 & 0.067 & 5.944 & 1.270 & 0.031 & 211 & 1155 \\
\hline National Penn Bancshares Inc & NPBC & 0.010 & 0.188 & 7.203 & 1.303 & 0.022 & 1549 & 9751 \\
\hline Northern Trust Corp & NTRS & 0.007 & 0.416 & 12.013 & 1.862 & -0.021 & 15731 & 109946 \\
\hline Norwood Financial Corp & NWFL & 0.011 & -0.034 & 6.189 & 1.079 & 0.037 & 107 & 712 \\
\hline OFG Bancorp & OFG & 0.011 & 0.198 & 6.906 & 0.790 & 0.063 & 744 & 7449 \\
\hline Southwest Bancorp Inc OK & OKSB & 0.011 & 0.278 & 6.172 & 1.230 & 0.029 & 333 & 1942 \\
\hline Old Line Bancshares & OLBK & 0.006 & -0.008 & 8.034 & 1.264 & 0.036 & 171 & 1222 \\
\hline Old National Bancorp & ONB & 0.009 & 0.215 & 6.947 & 1.186 & 0.019 & 1739 & 11648 \\
\hline Old Point Financial Corp & OPOF & 0.005 & -0.383 & 8.902 & 0.841 & 0.024 & 74 & 876 \\
\hline Oritani Financial Corp & ORIT & 0.013 & -0.107 & 5.401 & 1.348 & 0.041 & 685 & 3250 \\
\hline Orrstown Financial Services Inc & ORRF & 0.024 & 0.122 & 8.354 & 1.104 & 0.019 & 140 & 1190 \\
\hline Old Second Bancorp Inc & OSBC & 0.005 & 0.166 & 9.619 & 0.814 & 0.024 & 158 & 2062 \\
\hline Ohio Valley Banc Corp & OVBC & 0.010 & 0.054 & 8.032 & 1.172 & 0.037 & 101 & 779 \\
\hline Bank of The Ozarks Inc & OZRK & 0.018 & 0.306 & 6.421 & 3.324 & 0.035 & 3031 & 6766 \\
\hline PacWest Bancorp DE & PACW & 0.010 & -0.090 & 3.631 & 1.336 & 0.049 & 4683 & 16237 \\
\hline Prosperity Bancshares Inc & PB & 0.014 & 0.019 & 5.632 & 1.190 & 0.032 & 3862 & 21519 \\
\hline Porter Bancorp Inc & PBIB & -0.011 & -0.179 & 29.420 & 0.214 & 0.042 & 7 & 1018 \\
\hline Pacific Continental Corp & PCBK & 0.011 & 0.089 & 7.169 & 1.364 & 0.041 & 251 & 1504 \\
\hline Peoples Bancorp NC Inc & PEBK & 0.009 & 0.033 & 9.546 & 1.023 & 0.028 & 101 & 1040 \\
\hline Peoples Bancorp Inc & PEBO & 0.006 & 0.170 & 6.550 & 1.131 & 0.017 & 385 & 2568 \\
\hline Premier Financial Bancorp Inc & PFBI & 0.010 & -0.039 & 7.594 & 0.870 & 0.039 & 127 & 1253 \\
\hline Peoples Financial Corp MS & PFBX & -0.015 & 0.020 & 6.045 & 0.672 & 0.025 & 64 & 669 \\
\hline Peapack Gladstone Financial Corp & PGC & 0.006 & 0.107 & 10.155 & 1.161 & 0.021 & 281 & 2702 \\
\hline Parke Bancorp Inc & PKBK & 0.013 & -0.103 & 6.974 & 0.672 & 0.039 & 69 & 822 \\
\hline Pacific Mercantile Bancorp & PMBC & 0.000 & 0.179 & 8.219 & 1.149 & 0.032 & 137 & 1100 \\
\hline PNC Financial Services Group Inc & PNC & 0.012 & 0.486 & 6.493 & 1.042 & 0.009 & 48006 & 345243 \\
\hline Pinnacle Financial Partners Inc & PNFP & 0.012 & -0.087 & 6.497 & 1.760 & 0.028 & 1413 & 6018 \\
\hline Park Sterling Bank & PSTB & 0.005 & -0.004 & 7.609 & 1.199 & 0.034 & 330 & 2368 \\
\hline Privatebancorp Inc & PVTB & 0.010 & 0.670 & 9.531 & 1.762 & 0.027 & 2611 & 15603 \\
\hline Penns Woods Bancorp Inc & PWOD & 0.012 & 0.078 & 8.157 & 1.741 & 0.030 & 237 & 1245 \\
\hline Republic Bancorp Inc KY & RBCAA & 0.008 & -0.237 & 5.706 & 0.823 & 0.025 & 460 & 3747 \\
\hline Royal Bancshares PA Inc & RBPAA & 0.007 & -0.059 & 10.701 & 0.715 & 0.038 & 45 & 733 \\
\hline Regions Financial Corp & RF & 0.010 & 0.401 & 6.057 & 0.856 & 0.016 & 14536 & 119889 \\
\hline Sandy Spring Bancorp Inc & SASR & 0.009 & 0.139 & 7.428 & 1.252 & 0.025 & 653 & 4397 \\
\hline Seacoast Banking Corp FL & SBCF & 0.002 & 0.182 & 8.894 & 1.457 & 0.020 & 456 & 3093 \\
\hline SB Financial Group Inc & SBFG & 0.008 & 0.142 & 8.041 & 0.605 & 0.019 & 46 & 684 \\
\hline Southside Bancshares Inc & SBSI & 0.004 & -0.011 & 10.305 & 1.639 & 0.024 & 697 & 4807 \\
\hline Southern First Bancshares Inc & SFST & 0.006 & 0.055 & 11.410 & 1.275 & 0.036 & 106 & 1030 \\
\hline Southwest Georgia Financial Corp & SGB & 0.008 & -0.088 & 9.901 & 1.067 & 0.029 & 37 & 374 \\
\hline Shore Bancshares Inc & SHBI & 0.005 & -0.406 & 6.834 & 0.839 & 0.022 & 118 & 1100 \\
\hline SVB Financial Group & SIVB & 0.007 & 0.260 & 8.701 & 1.457 & 0.008 & 5911 & 39352 \\
\hline Sun Bancorp Inc NJ & SNBC & -0.011 & 0.483 & 10.079 & 1.472 & 0.029 & 361 & 2718 \\
\hline Synovus Financial Corp & SNV & 0.007 & 0.409 & 7.895 & 1.217 & 0.028 & 3700 & 27051 \\
\hline Southern National Bancorp VA Inc & SONA & 0.008 & 0.065 & 7.042 & 1.215 & 0.042 & 139 & 917 \\
\hline 1st Source Corp & SRCE & 0.012 & -0.244 & 6.861 & 1.332 & 0.022 & 819 & 4830 \\
\hline South State Corp & SSB & 0.010 & 0.074 & 6.953 & 1.645 & 0.037 & 1620 & 7833 \\
\hline Stewardship Financial Corp & SSFN & 0.004 & 0.043 & 10.762 & 0.498 & 0.034 & 29 & 694 \\
\hline S \& T Bancorp Inc & STBA & 0.012 & 0.327 & 7.160 & 1.460 & 0.025 & 888 & 4965 \\
\hline State Bank Financial Corp & STBZ & 0.011 & 0.503 & 5.210 & 1.389 & 0.057 & 645 & 2882 \\
\hline SunTrust Banks Inc & STI & 0.009 & 0.422 & 7.279 & 0.950 & 0.011 & 21849 & 190447 \\
\hline State Street Corp & STT & 0.007 & 0.204 & 11.764 & 1.526 & -0.023 & 32773 & 274119 \\
\hline Severn Bancorp Inc MD & SVBI & 0.004 & -0.016 & 8.266 & 0.545 & 0.038 & 46 & 777 \\
\hline Stock Yards Bancorp Inc & SYBT & 0.014 & 0.253 & 8.866 & 1.892 & 0.020 & 492 & 2564 \\
\hline
\end{tabular}




\begin{tabular}{|c|c|c|c|c|c|c|c|c|}
\hline Firm & Ticker & ROA & GAP 12 & $\mathbf{D} / \mathbf{E}$ & MB & NIM & MKT Cap & TA \\
\hline Bancorp Inc & TBBK & 0.011 & 0.565 & 14.630 & 1.287 & -0.002 & 411 & 4986 \\
\hline TCF Financial Corp & $\mathrm{TCB}$ & 0.009 & 0.226 & 8.098 & 1.244 & 0.026 & 2657 & 19427 \\
\hline Texas Capital Bancshares Inc & TCBI & 0.009 & 0.888 & 9.707 & 1.673 & 0.031 & 2485 & 15900 \\
\hline Trico Bancshares & TCBK & 0.007 & 0.145 & 8.366 & 1.342 & 0.024 & 561 & 3916 \\
\hline Community Financial Corp MD & TCFC & 0.006 & -0.013 & 8.290 & 0.810 & 0.038 & 94 & 1083 \\
\hline First Financial Corp IN & THFF & 0.011 & 0.077 & 6.607 & 1.169 & 0.026 & 461 & 2999 \\
\hline Talmer Bancorp Inc & TLMR & 0.015 & -0.162 & 6.704 & 1.300 & 0.016 & 990 & 5868 \\
\hline Two River Bancorp & TRCB & 0.008 & 0.139 & 7.317 & 0.713 & 0.038 & 67 & 781 \\
\hline Trustmark Corp & TRMK & 0.010 & 0.112 & 7.628 & 1.166 & 0.024 & 1656 & 12251 \\
\hline TrustCo Bank Corp NY & TRST & 0.010 & -0.121 & 10.805 & 1.750 & 0.029 & 689 & 4645 \\
\hline United Security Bankshares & UBFO & 0.009 & 0.343 & 7.007 & 1.007 & 0.035 & 83 & 663 \\
\hline United Financial Bancorp Inc & UBNK & 0.001 & 0.010 & 8.101 & 1.181 & 0.027 & 711 & 5483 \\
\hline United Bancshares Inc & UBOH & 0.007 & 0.052 & 8.594 & 0.718 & 0.026 & 49 & 650 \\
\hline Union Bankshares Corp & UBSH & 0.007 & 0.152 & 6.529 & 1.112 & 0.033 & 1088 & 7364 \\
\hline United Bankshares Inc & UBSI & 0.011 & -0.248 & 6.444 & 1.567 & 0.031 & 2595 & 12329 \\
\hline United Community Banks Inc GA & UCBI & 0.009 & 0.157 & 9.234 & 1.543 & 0.027 & 1141 & 7569 \\
\hline UMB Financial Corp & UMBF & 0.007 & 0.059 & 9.647 & 1.576 & -0.008 & 2590 & 17501 \\
\hline Umpqua Holdings Corp & UMPQ & 0.007 & -0.156 & 4.983 & 0.990 & 0.034 & 3745 & 22622 \\
\hline Union Bankshares Inc & UNB & 0.012 & 0.184 & 11.133 & 2.059 & 0.028 & 106 & 624 \\
\hline Unity Bancorp Inc & UNTY & 0.006 & 0.132 & 13.386 & 1.128 & 0.034 & 79 & 1009 \\
\hline US Bancorp DE & USB & 0.015 & 0.322 & 8.114 & 1.821 & 0.009 & 80433 & 402529 \\
\hline Univest Corp of Pennsylvania & UVSP & 0.010 & 0.229 & 6.856 & 1.154 & 0.014 & 328 & 2235 \\
\hline Village Bank \& Trust Financial Corp & VBFC & -0.002 & 0.014 & 21.684 & 0.405 & 0.023 & 8 & 432 \\
\hline Western Alliance Bancorporation & WAL & 0.014 & 0.043 & 9.591 & 2.446 & 0.039 & 2449 & 10600 \\
\hline Washington Trust Bancorp Inc & WASH & 0.011 & 0.196 & 9.361 & 1.943 & 0.019 & 673 & 3588 \\
\hline Webster Financial Corp & WBS & 0.009 & 0.263 & 8.707 & 1.264 & 0.025 & 2936 & 22545 \\
\hline Washington First Bancshares Inc & WFBI & 0.007 & 0.192 & 8.936 & 0.871 & 0.039 & 117 & 1337 \\
\hline Wells Fargo \& Co & WFC & 0.014 & 0.328 & 8.100 & 1.534 & 0.005 & 284386 & 1687155 \\
\hline Wilshire Bancorp Inc & WIBC & 0.014 & 0.097 & 7.491 & 1.621 & 0.032 & 793 & 4155 \\
\hline WSFS Financial Corp & WSFS & 0.011 & 0.429 & 8.924 & 1.478 & 0.020 & 723 & 4853 \\
\hline WinTrust Financial Corporation & WTFC & 0.008 & 0.384 & 8.678 & 1.057 & 0.025 & 2189 & 20032 \\
\hline Yadkin Financial Corp & YDKN & 0.005 & 0.262 & 6.648 & 1.113 & 0.029 & 621 & 4266 \\
\hline Zions Bancorporation & ZION & 0.007 & 0.517 & 6.763 & 0.785 & 0.026 & 5788 & 57209 \\
\hline \multicolumn{9}{|l|}{ Savings Banks } \\
\hline Anchor Bancorp WA & ANCB & 0.025 & 0.045 & 5.025 & 0.806 & 0.044 & 51 & 378 \\
\hline Access National Corp & ANCX & 0.013 & 0.141 & 9.645 & 1.791 & 0.019 & 177 & 1053 \\
\hline A S B Bancorp Inc & ASBB & 0.003 & 0.208 & 7.052 & 0.997 & 0.025 & 94 & 760 \\
\hline Bank Financial Corp & BFIN & 0.028 & 0.212 & 5.781 & 1.158 & 0.032 & 250 & 1465 \\
\hline Bancorp of New Jersey Inc & BKJ & 0.006 & 0.031 & 11.294 & 1.014 & 0.038 & 61 & 745 \\
\hline BankUnited Inc & BKU & 0.011 & -0.216 & 8.359 & 1.435 & 0.041 & 2945 & 19211 \\
\hline B of I Holding Inc & BOFI & 0.013 & -0.346 & 10.533 & 2.595 & 0.038 & 1169 & 5195 \\
\hline Carver Bancorp Inc & CARV & -0.002 & 0.079 & 10.891 & 0.426 & 0.026 & 23 & 644 \\
\hline Meta Financial Group Inc & CASH & 0.007 & 0.071 & 10.477 & 1.185 & 0.000 & 218 & 2108 \\
\hline Cape Bancorp Inc & CBNJ & 0.006 & -0.074 & 6.665 & 0.766 & 0.039 & 108 & 1080 \\
\hline Chicopee Bancorp Inc & CBNK & -0.001 & 0.026 & 6.253 & 1.002 & 0.034 & 88 & 639 \\
\hline Capitol Federal Financial Inc & CFFN & 0.009 & -0.019 & 5.187 & 1.226 & 0.031 & 1798 & 9069 \\
\hline Clifton Bancorp Inc & CSBK & 0.006 & -0.145 & 2.294 & 1.014 & 0.030 & 369 & 1198 \\
\hline Citizens Community Bancorp Inc MD & CZWI & 0.004 & -0.048 & 8.745 & 0.811 & 0.036 & 48 & 571 \\
\hline ESSA Bancorp Inc & ESSA & 0.006 & -0.402 & 8.250 & 0.810 & 0.031 & 137 & 1568 \\
\hline Flagstar Bancorp Inc & $\mathrm{FBC}$ & -0.007 & 0.237 & 6.168 & 0.645 & -0.007 & 885 & 9840 \\
\hline 1st Constitution Bancorp & FCCY & 0.005 & 0.126 & 9.984 & 0.892 & 0.035 & 78 & 957 \\
\hline First Clover Leaf Financial Corp & FCLF & 0.006 & 0.108 & 6.878 & 0.796 & 0.032 & 61 & 608 \\
\hline First Defiance Financial Corp & FDEF & 0.011 & -0.281 & 6.796 & 1.125 & 0.023 & 315 & 2179 \\
\hline Flushing Financial Corp & FFIC & 0.009 & 0.046 & 10.128 & 1.306 & 0.041 & 596 & 5077 \\
\hline First Financial Northwest Inc & FFNW & 0.011 & 0.047 & 4.165 & 1.007 & 0.043 & 183 & 937 \\
\hline First Niagara Financial Group Inc & FNFG & -0.019 & 0.349 & 8.420 & 0.728 & 0.026 & 2979 & 38558 \\
\hline First Savings Financial Group Inc & FSFG & 0.008 & -0.086 & 7.027 & 0.642 & 0.036 & 57 & 718 \\
\hline Fox Chase Bancorp Inc & $\mathrm{FXCB}$ & 0.007 & 0.188 & 5.242 & 1.118 & 0.036 & 197 & 1098 \\
\hline
\end{tabular}




\begin{tabular}{|c|c|c|c|c|c|c|c|c|}
\hline Firm & Ticker & ROA & GAP 12 & $\mathbf{D} / \mathbf{E}$ & MB & NIM & MKT Cap & TA \\
\hline Home Bancorp Inc & HBCP & 0.008 & 0.130 & 6.924 & 1.060 & 0.041 & 163 & 1221 \\
\hline Hopfed Bancorp Inc & HFBC & 0.002 & 0.157 & 8.510 & 0.927 & 0.035 & 91 & 936 \\
\hline Heritage Financial Corp WA & HFWA & 0.006 & 0.064 & 6.608 & 1.168 & 0.033 & 531 & 3458 \\
\hline HomeTrust Bancshares Inc & HTBI & 0.003 & 0.111 & 5.931 & 0.894 & 0.026 & 341 & 2640 \\
\hline Investors Bancorp Inc & ISBC & 0.007 & 0.003 & 4.233 & 1.123 & 0.035 & 4019 & 18722 \\
\hline MB Financial Inc & MBFI & 0.006 & 0.277 & 6.199 & 1.211 & 0.009 & 2457 & 14602 \\
\hline Mackinac Financial Corp & MFNC & 0.002 & -0.075 & 9.052 & 1.004 & 0.036 & 74 & 744 \\
\hline Malvern Bancorp Inc & MLVF & 0.001 & -0.054 & 6.744 & 1.018 & 0.031 & 79 & 603 \\
\hline Northfield Bancorp Inc DE & NFBK & 0.007 & 0.022 & 4.086 & 1.206 & 0.030 & 716 & 3021 \\
\hline Northrim Bancorp Inc & NRIM & 0.012 & 0.254 & 7.814 & 1.094 & 0.029 & 180 & 1449 \\
\hline Northwest Bancshares Inc & NWBI & 0.008 & 0.142 & 6.357 & 1.117 & 0.035 & 1187 & 7818 \\
\hline NY Community Bancorp Inc & NYCB & 0.010 & -0.017 & 7.399 & 1.225 & 0.035 & 7082 & 48559 \\
\hline OceanFirst Financial Corp & OCFC & 0.008 & 0.195 & 9.817 & 1.327 & 0.029 & 290 & 2361 \\
\hline Ocean Shore Holding Co & OSHC & 0.006 & 0.028 & 8.685 & 0.865 & 0.033 & 92 & 1025 \\
\hline Peoples United Financial Inc & PBCT & 0.007 & 0.229 & 6.767 & 1.008 & 0.021 & 4672 & 35986 \\
\hline Prudential Bancorp Inc & PBIP & 0.004 & -0.013 & 3.114 & 0.914 & 0.031 & 117 & 527 \\
\hline Provident Financial Services Inc & PFS & 0.009 & 0.074 & 6.449 & 1.031 & 0.031 & 1179 & 8523 \\
\hline Pacific Premier Bancorp Inc & PPBI & 0.008 & 0.152 & 9.215 & 1.468 & 0.036 & 293 & 2039 \\
\hline Provident Financial Holdings Inc & PROV & 0.007 & 0.272 & 6.706 & 0.943 & 0.003 & 136 & 1112 \\
\hline Pulaski Financial Corp & PULB & 0.008 & 0.195 & 11.457 & 1.260 & 0.026 & 144 & 1426 \\
\hline Riverview Bancorp Inc & RVSB & 0.024 & 0.023 & 7.088 & 0.983 & 0.029 & 101 & 828 \\
\hline SI Financial Group Inc MD & SIFI & 0.003 & 0.090 & 7.551 & 0.918 & 0.030 & 145 & 1349 \\
\hline Southern Missouri Bancorp Inc & SMBC & 0.009 & 0.015 & 8.976 & 1.079 & 0.035 & 140 & 1296 \\
\hline Sterling Bancorp DE & STL & 0.008 & 0.224 & 6.619 & 1.237 & 0.032 & 1206 & 7430 \\
\hline Territorial Bancorp Inc & TBNK & 0.008 & -0.059 & 6.819 & 0.988 & 0.035 & 214 & 1692 \\
\hline Timberland Bancorp Inc & TSBK & 0.008 & 0.248 & 7.899 & 0.887 & 0.032 & 75 & 750 \\
\hline United Community Bancorp & UCBA & 0.004 & -0.035 & 6.190 & 0.761 & 0.025 & 54 & 509 \\
\hline United Community Financial Corp Ohio & UCFC & 0.027 & 0.137 & 6.645 & 1.101 & 0.029 & 264 & 1836 \\
\hline Washington Federal Inc & WAFD & 0.011 & -0.053 & 6.316 & 1.091 & 0.039 & 2161 & 14495 \\
\hline Westbury Bancorp Inc & WBB & -0.002 & 0.220 & 5.872 & 0.951 & 0.024 & 82 & 595 \\
\hline \multicolumn{9}{|l|}{ Bank Holding Companies } \\
\hline Ameris Bancorp & $\mathrm{ABCB}$ & 0.010 & 0.197 & 10.046 & 0.170 & 0.029 & 686 & 4043 \\
\hline Astoria Financial Corp & $\mathrm{AF}$ & 0.006 & 0.084 & 8.898 & 0.085 & 0.031 & 1333 & 15640 \\
\hline American River Bankshares & AMRB & 0.007 & -0.049 & 5.891 & 0.123 & 0.031 & 76 & 618 \\
\hline Arrow Financial Corp & AROW & 0.011 & 0.062 & 10.033 & 0.157 & 0.018 & 349 & 2217 \\
\hline AmeriServ Financial Inc & ASRV & 0.003 & 0.071 & 8.521 & 0.054 & 0.027 & 59 & 1089 \\
\hline Ames National Corp & ATLO & 0.012 & 0.105 & 7.411 & 0.186 & 0.028 & 242 & 1301 \\
\hline Auburn National Bancorp & AUBN & 0.009 & 0.080 & 9.412 & 0.109 & 0.029 & 86 & 789 \\
\hline Bar Harbor Bankshares & BHB & 0.010 & -0.218 & 8.976 & 0.130 & 0.034 & 190 & 1459 \\
\hline Berkshire Hills Bancorp Inc & BHLB & 0.005 & 0.127 & 8.173 & 0.103 & 0.027 & 671 & 6506 \\
\hline Bryn Mawr Bank Corp & BMTC & 0.012 & 0.174 & 8.152 & 0.192 & 0.018 & 431 & 2247 \\
\hline BNC Bancorp & $\mathrm{BNCN}$ & 0.007 & -0.401 & 9.432 & 0.138 & 0.037 & 561 & 4073 \\
\hline Boston Private Financial Holdings Inc & BPFH & 0.010 & 0.164 & 8.379 & 0.164 & 0.010 & 1117 & 6798 \\
\hline Brookline Bancorp Inc & BRKL & 0.007 & 0.119 & 7.985 & 0.121 & 0.037 & 702 & 5800 \\
\hline First Busey Corp & BUSE & 0.009 & 0.219 & 7.453 & 0.154 & 0.015 & 565 & 3666 \\
\hline Baylake Corp & BYLK & 0.009 & -0.183 & 8.688 & 0.111 & 0.029 & 113 & 1022 \\
\hline Cascade Bancorp & $\mathrm{CACB}$ & 0.002 & 0.110 & 6.421 & 0.161 & 0.025 & 376 & 2341 \\
\hline California First National Bancor & CFNB & 0.014 & 0.192 & 2.452 & 0.232 & 0.023 & 148 & 639 \\
\hline Cardinal Financial Corp & CFNL & 0.010 & 0.063 & 8.009 & 0.187 & 0.028 & 636 & 3399 \\
\hline City Holding Co & $\mathrm{CHCO}$ & 0.015 & 0.184 & 7.855 & 0.204 & 0.023 & 705 & 3461 \\
\hline Charter Financial Corp & CHFN & 0.006 & 0.115 & 3.604 & 0.198 & 0.026 & 194 & 981 \\
\hline Citizens Holding Co & CIZN & 0.008 & 0.288 & 10.252 & 0.103 & 0.029 & 95 & 921 \\
\hline Carolina Bank Holdings Inc & CLBH & 0.005 & 0.140 & 11.919 & 0.049 & 0.027 & 33 & 680 \\
\hline CoBiz Financial Inc & COBZ & 0.009 & 0.262 & 8.917 & 0.175 & 0.029 & 535 & 3062 \\
\hline Community Trust Bancorp Inc & CTBI & 0.012 & 0.244 & 7.314 & 0.172 & 0.029 & 639 & 3724 \\
\hline Central Valley Community Bancorp & CVCY & 0.004 & 0.085 & 8.098 & 0.102 & 0.032 & 122 & 1192 \\
\hline Codorus Valley Bancorp Inc & CVLY & 0.010 & 0.036 & 9.249 & 0.095 & 0.037 & 115 & 1214 \\
\hline Community West Bancshares & CWBC & 0.013 & 0.181 & 7.317 & 0.097 & 0.047 & 54 & 557 \\
\hline
\end{tabular}




\begin{tabular}{|c|c|c|c|c|c|c|c|c|}
\hline Firm & Ticker & ROA & GAP 12 & $\mathbf{D} / \mathbf{E}$ & MB & NIM & MKT Cap & TA \\
\hline Citizens \& Northern Corp & $\mathrm{CZNC}$ & 0.014 & -0.024 & 5.593 & 0.204 & 0.026 & 254 & 1242 \\
\hline Dime Community Bancshares & DCOM & 0.010 & -0.190 & 8.782 & 0.133 & 0.039 & 600 & 4497 \\
\hline D N B Financial Corp & DNBF & 0.007 & 0.061 & 10.324 & 0.083 & 0.028 & 60 & 724 \\
\hline Enterprise Bancorp Inc & EBTC & 0.007 & 0.189 & 11.113 & 0.127 & 0.034 & 258 & 2022 \\
\hline First Business Financial Services Inc & FBIZ & 0.009 & 0.233 & 10.829 & 0.127 & 0.030 & 208 & 1629 \\
\hline First Community Corp SS & FCCO & 0.006 & 0.073 & 9.903 & 0.093 & 0.026 & 75 & 813 \\
\hline First Interstate BancSystem Inc & FIBK & 0.010 & 0.203 & 8.467 & 0.071 & 0.020 & 610 & 8605 \\
\hline Park National Corp & PRK & 0.012 & -0.155 & 9.025 & 0.195 & 0.030 & 1363 & 7003 \\
\hline Renasant Corp & RNST & 0.010 & 0.218 & 7.157 & 0.157 & 0.029 & 913 & 5805 \\
\hline Salisbury Bancorp Inc & SAL & 0.003 & 0.100 & 7.401 & 0.087 & 0.021 & 74 & 855 \\
\hline Sussex Bancorp & SBBX & 0.004 & -0.245 & 10.632 & 0.080 & 0.028 & 48 & 596 \\
\hline Simmons 1st National Corp & SFNC & 0.008 & 0.104 & 8.393 & 0.158 & 0.024 & 734 & 4643 \\
\hline Tompkins Financial Corp & TMP & 0.010 & 0.140 & 9.763 & 0.155 & 0.023 & 816 & 5270 \\
\hline United Security Bancshares Inc & USBI & 0.006 & -0.003 & 6.618 & 0.093 & 0.052 & 53 & 573 \\
\hline Westamerica Bancorporation & WABC & 0.012 & -0.190 & 8.564 & 0.251 & 0.019 & 1262 & 5036 \\
\hline West Bancorporation Inc & WTBA & 0.012 & 0.108 & 10.527 & 0.169 & 0.031 & 273 & 1616 \\
\hline \multicolumn{9}{|c|}{ Investment Banks, Security Dealers/Brokers, Advisory Services } \\
\hline American National Bankshares Inc & AMNB & 0.009 & 0.165 & 6.748 & 1.124 & 0.030 & 195 & 1346 \\
\hline Goldman Sachs Group Inc & GS & 0.010 & 0.487 & 9.292 & 1.015 & -0.027 & 84422 & 856301 \\
\hline HomeStreet Inc & HMST & 0.006 & -0.128 & 10.695 & 0.856 & -0.023 & 259 & 3535 \\
\hline Morgan Stanley Dean Witter \& Co & MS & 0.004 & 0.419 & 10.116 & 1.053 & -0.035 & 75947 & 801510 \\
\hline Raymond James Financial Inc & RJF & 0.020 & 0.607 & 4.321 & 1.779 & -0.216 & 8110 & 24253 \\
\hline Schwab Charles Corp New & SCHW & 0.009 & -0.074 & 12.102 & 3.340 & -0.009 & 39421 & 154642 \\
\hline Stifel Financial Corp & SF & 0.018 & 0.485 & 3.099 & 1.450 & -0.286 & 3368 & 9518 \\
\hline WesBanco Inc & WSBC & 0.011 & -0.202 & 6.992 & 1.294 & 0.027 & 1020 & 6300 \\
\hline \multicolumn{9}{|l|}{ Other Finance } \\
\hline American Express Co & AXP & 0.037 & 0.439 & 6.693 & 4.655 & -0.154 & 96266 & 159103 \\
\hline Banner Corp & BANR & 0.011 & 0.169 & 7.094 & 1.443 & 0.030 & 842 & 4724 \\
\hline Bank Mutual Corp & BKMU & 0.006 & 0.108 & 7.185 & 1.123 & 0.027 & 319 & 2328 \\
\hline B O K Financial Corp & $\mathrm{BOKF}$ & 0.010 & 0.243 & 7.737 & 1.244 & 0.005 & 4150 & 29148 \\
\hline Cass Information Systems Inc & CASS & 0.016 & -0.017 & 6.487 & 3.056 & -0.031 & 613 & 1501 \\
\hline Colony Bankcorp Inc & CBAN & 0.007 & 0.068 & 10.582 & 0.672 & 0.035 & 66 & 1147 \\
\hline Community Bank System Inc & $\mathrm{CBU}$ & 0.012 & 0.051 & 6.581 & 1.567 & 0.020 & 1548 & 7489 \\
\hline Cullen Frost Bankers Inc & CFR & 0.010 & 0.440 & 8.942 & 1.562 & 0.015 & 4454 & 28348 \\
\hline Cheviot Financial Corp & CHEV & 0.005 & 0.128 & 4.941 & 0.993 & 0.032 & 95 & 571 \\
\hline CU Bancorp & CUNB & 0.004 & 0.398 & 7.113 & 1.300 & 0.023 & 363 & 2265 \\
\hline Emclaire Financial Corp & EMCF & 0.007 & 0.084 & 11.126 & 0.928 & 0.031 & 45 & 582 \\
\hline E Trade Financial Corp & ETFC & 0.006 & 0.136 & 7.471 & 1.305 & 0.015 & 7016 & 45530 \\
\hline First American Financial Corp & FAF & 0.030 & 0.501 & 1.976 & 1.412 & -1.034 & 3636 & 7666 \\
\hline First Marblehead Corp & FMD & -0.100 & 0.239 & 2.632 & 0.561 & -0.232 & 69 & 444 \\
\hline Hilltop Holdings Inc & HTH & 0.012 & 0.257 & 5.325 & 1.231 & -0.052 & 1799 & 9242 \\
\hline Marlin Business Services Corp & MRLN & 0.025 & -0.113 & 3.418 & 1.515 & 0.098 & 264 & 769 \\
\hline Oak Valley Bancorp & OVLY & 0.010 & 0.257 & 8.994 & 1.094 & 0.034 & 82 & 749 \\
\hline Plumas Bancorp & PLBC & 0.009 & 0.180 & 13.765 & 1.050 & 0.029 & 38 & 539 \\
\hline QCR Holdings Inc & QCRH & 0.006 & -0.206 & 16.525 & 0.986 & 0.028 & 142 & 2525 \\
\hline Tristate Capital Holdings Inc & TSC & 0.006 & 0.501 & 8.322 & 0.941 & 0.018 & 287 & 2847 \\
\hline Valley National Bancorp & VLY & 0.006 & 0.095 & 9.088 & 1.207 & 0.034 & 2248 & 18794 \\
\hline
\end{tabular}

In this table, we present selected financial data for our sample. We obtain data for market capitalization from CRSP and balance sheet and income statement information from each firm's FR Y-9C, available from the Federal Reserve Bank of Chicago, as of December 31, 2014. We classify firms into industry subsectors according to their NAICS code, obtained from CRSP. Total Assets and Market Capitalization are in millions of US dollars. Variable definitions are provided in the Data and Sample Section. 
TABLE 2A

SHARE PRICE RESPONSE TO THE FED'S INTEREST RATE ANNOUNCEMENT

\begin{tabular}{|c|c|c|c|c|c|c|c|}
\hline Firm & Ticker & $\alpha_{i}$ & & $\beta_{\mathrm{i}}$ & & $\gamma_{i}$ & \\
\hline \multicolumn{8}{|l|}{ Commercial Banks } \\
\hline Atlantic Coast Financial Corp & $\mathrm{ACFC}$ & -0.045 & $* * *$ & -0.255 & & 0.068 & \\
\hline ACNB Corp & ACNB & -0.136 & $* * *$ & 0.550 & & 0.142 & \\
\hline Bank of America Corp & $\mathrm{BAC}$ & 0.000 & & 1.379 & $* * *$ & -0.034 & $* * *$ \\
\hline Banc of California Inc & BANC & 0.001 & $*$ & 0.825 & $* * *$ & -0.013 & \\
\hline BancFirst Corp & BANF & 0.000 & & 0.909 & $* * *$ & -0.014 & \\
\hline BBCN Bancorp Inc & $\mathrm{BBCN}$ & 0.000 & & 1.132 & $* * *$ & -0.032 & $* *$ \\
\hline BB \& T Corp & BBT & 0.000 & & 1.043 & $* * *$ & -0.029 & $* * *$ \\
\hline BCB Bancorp Inc & BCBP & -0.137 & $* * *$ & -0.629 & & 0.153 & \\
\hline Bridge Bancorp Inc & BDGE & 0.001 & & 0.805 & $* * *$ & -0.018 & \\
\hline Bank of NY Mellon Corp & BK & 0.000 & & 1.139 & $* * *$ & -0.015 & \\
\hline Bank South Carolina Corp & BKSC & -0.221 & $* * *$ & 5.650 & & 0.236 & \\
\hline BSB Bancorp Inc MD & BLMT & -0.008 & & -0.004 & & 0.003 & \\
\hline Bank of Marin Bancorp & BMRC & 0.000 & & 0.522 & $* * *$ & 0.010 & \\
\hline Bank of Commerce Holdings & $\mathrm{BOCH}$ & -0.018 & $* *$ & 0.069 & & 0.018 & \\
\hline Bank of Hawaii Corp & $\mathrm{BOH}$ & 0.001 & & 0.977 & $* * *$ & -0.027 & $* * *$ \\
\hline Popular Inc & BPOP & 0.000 & & 1.184 & $* * *$ & -0.027 & $* *$ \\
\hline Sierra Bancorp & BSRR & 0.001 & & 0.986 & $* * *$ & -0.009 & \\
\hline BancorpSouth Inc & BXS & 0.000 & & 1.319 & $* * *$ & -0.022 & * \\
\hline Citigroup Inc & $\mathrm{C}$ & 0.000 & & 1.467 & $* * *$ & -0.024 & $* *$ \\
\hline Camden National Corp & $\mathrm{CAC}$ & 0.000 & & 0.769 & $* * *$ & -0.004 & \\
\hline Cathay General Bancorp & CATY & 0.001 & & 1.251 & $* * *$ & -0.029 & $* *$ \\
\hline Capital Bank Financial Corp & $\mathrm{CBF}$ & 0.001 & & 0.867 & $* * *$ & -0.045 & $* * *$ \\
\hline Commerce Bancshares Inc & $\mathrm{CBSH}$ & 0.000 & & 0.949 & $* * *$ & -0.023 & $* *$ \\
\hline Capital City Bank Group & CCBG & 0.000 & & 0.788 & $* * *$ & -0.007 & \\
\hline CNB Financial Corp PA & CCNE & 0.000 & & 0.815 & $* * *$ & -0.006 & \\
\hline C \& F Financial Corp & CFFI & -0.091 & $* * *$ & 2.083 & & 0.072 & \\
\hline Chemical Financial Corp & CHFC & 0.001 & & 0.933 & $* * *$ & -0.019 & $*$ \\
\hline Chemung Financial Corp & CHMG & -0.213 & $* * *$ & 2.015 & & -1.784 & $* * *$ \\
\hline CIT Group Inc & CIT & -0.001 & & 1.160 & $* * *$ & -0.022 & \\
\hline Comerica Inc & CMA & 0.000 & & 1.390 & $* * *$ & -0.042 & $* * *$ \\
\hline Century Bancorp Inc & CNBKA & 0.000 & & 0.693 & $* * *$ & 0.000 & \\
\hline CommunityOne Bancorp & $\mathrm{COB}$ & 0.001 & & 1.178 & $* * *$ & 0.019 & \\
\hline Capital One Financial Corp & $\mathrm{COF}$ & 0.000 & & 1.157 & $* * *$ & -0.022 & * \\
\hline Columbia Banking System Inc & COLB & 0.001 & & 1.207 & $* * *$ & -0.031 & $*$ \\
\hline Central Pacific Financial Corp & $\mathrm{CPF}$ & 0.001 & & 0.999 & $* * *$ & -0.036 & $* *$ \\
\hline CenterState Banks Inc & CSFL & 0.001 & & 0.885 & $* * *$ & -0.022 & * \\
\hline Customers Bancorp Inc & CUBI & 0.001 & & 1.027 & $* * *$ & -0.030 & $*$ \\
\hline CVB Financial Corp & CVBF & 0.001 & & 1.244 & $* * *$ & -0.031 & $* * *$ \\
\hline Discover Financial Services & DFS & 0.000 & & 1.046 & $* * *$ & -0.008 & \\
\hline Eagle Bancorp Montana Inc & EBMT & -0.362 & $* * *$ & 9.374 & $* *$ & 0.328 & \\
\hline Enterprise Financial Services Corp & EFSC & 0.001 & $* *$ & 0.817 & $* * *$ & -0.003 & \\
\hline Eagle Bancorp Inc & EGBN & 0.001 & $*$ & 1.007 & $* * *$ & -0.009 & \\
\hline Community Bankers Trust Corp & ESXB & -0.036 & $* * *$ & -0.468 & & 0.040 & \\
\hline Evans Bancorp Inc & EVBN & -0.568 & $* * *$ & -1.228 & & -1.429 & \\
\hline Eastern VA Bankshares Inc & EVBS & -0.109 & $* * *$ & -2.049 & & 0.136 & \\
\hline EverBank Financial Corp & EVER & 0.000 & & 0.822 & $* * *$ & -0.016 & \\
\hline East West Bancorp Inc & EWBC & 0.000 & & 1.345 & $* * *$ & -0.036 & $* * *$ \\
\hline First Bancshares Inc MS & FBMS & -0.412 & $* * *$ & 3.657 & & -1.605 & $* *$ \\
\hline First Bancorp NC & FBNC & 0.000 & & 0.869 & $* * *$ & -0.007 & \\
\hline First Connecticut Bancorp Inc MD & FBNK & 0.000 & & 0.787 & $* * *$ & -0.018 & \\
\hline First Bancorp P R & FBP & 0.000 & & 2.056 & $* * *$ & -0.059 & $* *$ \\
\hline Fauquier Bankshares Inc & FBSS & -0.753 & $* * *$ & 5.450 & & -1.211 & \\
\hline First Community Bancshares Inc & FCBC & 0.001 & & 0.948 & $* * *$ & -0.004 & \\
\hline First Commonwealth Financial Corp & FCF & 0.000 & & 1.162 & $* * *$ & -0.030 & $* *$ \\
\hline First Citizens Bancshares Inc NC & FCNCA & 0.000 & & 1.106 & $* * *$ & -0.028 & $* *$ \\
\hline First Financial Bancorp Ohio & FFBC & 0.000 & & 1.042 & $* * *$ & -0.029 & $* *$ \\
\hline First Financial Bankshares Inc & FFIN & 0.000 & & 1.192 & $* * *$ & -0.036 & $* * *$ \\
\hline
\end{tabular}




\begin{tabular}{|c|c|c|c|c|c|c|c|}
\hline Firm & Ticker & $\alpha_{\mathrm{i}}$ & & $\beta_{\mathrm{i}}$ & & $\gamma_{i}$ & \\
\hline Farmers Capital Bank Corp & FFKT & 0.001 & & 0.315 & $* * *$ & -0.018 & \\
\hline First Horizon National Corp & FHN & 0.001 & & 1.214 & $* * *$ & -0.024 & $* *$ \\
\hline Financial Institutions Inc & FISI & 0.001 & & 0.812 & $* * *$ & -0.007 & \\
\hline Fifth Third Bancorp & FITB & 0.000 & & 1.262 & $* * *$ & -0.040 & $* * *$ \\
\hline First Long Island Corp & FLIC & 0.000 & & 0.915 & $* * *$ & 0.000 & \\
\hline First Midwest Bancorp DE & FMBI & 0.000 & & 1.160 & $* * *$ & -0.034 & $* * *$ \\
\hline FirstMerit Corp & FMER & 0.001 & & 1.215 & $* * *$ & -0.027 & $*$ \\
\hline Farmers National Banc Corp & FMNB & -0.018 & $* * *$ & -0.344 & & -0.001 & \\
\hline FNB Corp PA & FNB & 0.000 & & 1.126 & $* * *$ & -0.030 & $* * *$ \\
\hline First Bancorp Inc ME & FNLC & 0.000 & & 0.756 & $* * *$ & -0.006 & \\
\hline Republic First Bancorp Inc & FRBK & 0.000 & & 0.823 & $* * *$ & -0.031 & \\
\hline First Merchants Corp & FRME & 0.001 & & 0.977 & $* * *$ & -0.024 & $* *$ \\
\hline First South Bancorp Inc & FSBK & -0.172 & $* * *$ & -2.209 & & 0.190 & \\
\hline Fulton Financial Corp PA & FULT & 0.000 & & 1.012 & $* * *$ & -0.030 & $* * *$ \\
\hline First United Corp & FUNC & -0.090 & $* * *$ & 1.375 & & 0.085 & \\
\hline German American Bancorp Inc & GABC & 0.001 & & 0.855 & $* * *$ & -0.009 & \\
\hline Glacier Bancorp Inc & GBCI & 0.000 & & 1.379 & $* * *$ & -0.034 & $* * *$ \\
\hline Guaranty Bancorp & GBNK & 0.000 & & 0.879 & $* * *$ & -0.004 & \\
\hline Guaranty Federal Bancshares Inc & GFED & -0.499 & $* * *$ & 4.107 & & 0.497 & \\
\hline Great Southern Bancorp Inc & GSBC & 0.001 & & 1.124 & $* * *$ & -0.029 & $*$ \\
\hline Hanmi Financial Corp & HAFC & 0.000 & & 1.181 & $* * *$ & -0.036 & $* * *$ \\
\hline Huntington Bancshares Inc & HBAN & 0.000 & & 1.118 & $* * *$ & -0.036 & $* * *$ \\
\hline Hancock Holding Co & HBHC & -0.001 & & 1.511 & $* * *$ & -0.028 & $* * *$ \\
\hline Horizon Bancorp IN & HBNC & 0.000 & & 0.673 & $* * *$ & 0.007 & \\
\hline Heritage Oaks Bancorp & HEOP & 0.000 & & 0.998 & $* * *$ & -0.015 & \\
\hline HF Financial Corp & HFFC & -0.208 & $* * *$ & 1.702 & & 0.205 & \\
\hline HMN Financial Inc & HMNF & -0.308 & $* * *$ & 0.731 & & 0.306 & \\
\hline Hampton Roads Bankshares Inc & HMPR & 0.000 & & 1.208 & $* * *$ & 0.015 & \\
\hline Home BancShares Inc & HOMB & 0.001 & & 1.173 & $* * *$ & -0.019 & \\
\hline Heritage Commerce Corp & HTBK & 0.001 & & 0.736 & $* * *$ & -0.003 & \\
\hline Heartland Financial USA Inc & HTLF & 0.001 & & 1.041 & $* * *$ & -0.018 & \\
\hline Independent Bank Corp MI & $\mathrm{IBCP}$ & 0.000 & & 0.615 & $* * *$ & -0.018 & \\
\hline IberiaBank Corp & IBKC & 0.000 & & 1.245 & $* * *$ & -0.029 & $* *$ \\
\hline International Bancshares Corp & IBOC & 0.000 & & 1.430 & $* * *$ & -0.034 & $* *$ \\
\hline Independent Bank Group Inc & IBTX & -0.001 & & 1.418 & $* * *$ & -0.037 & $*$ \\
\hline First Internet Bancorp & INBK & 0.001 & & 0.595 & $* * *$ & 0.003 & \\
\hline Independent Bank Corp MA & INDB & 0.001 & & 1.052 & $* * *$ & -0.007 & \\
\hline IF Bancorp Inc & IROQ & -0.536 & $* * *$ & -0.243 & & 0.538 & \\
\hline JP Morgan Chase \& Co & JPM & 0.000 & & 1.227 & $* * *$ & -0.028 & $* * *$ \\
\hline KeyCorp & KEY & 0.000 & & 1.275 & $* * *$ & -0.036 & $* * *$ \\
\hline Lakeland Bancorp Inc & LBAI & 0.000 & & 1.103 & $* * *$ & -0.007 & \\
\hline LCNB Corp & LCNB & -0.027 & $* *$ & 0.559 & & 0.020 & \\
\hline Fidelity Southern Corp & LION & 0.001 & & 0.864 & $* * *$ & -0.019 & \\
\hline Lakeland Financial Corp & LKFN & 0.001 & & 0.761 & $* * *$ & -0.007 & \\
\hline Middleburg Financial Corp & MBRG & -0.081 & & 1.702 & & 0.086 & \\
\hline MBT Financial Corp & MBTF & -0.008 & & 0.196 & & 0.060 & \\
\hline Merchants Bancshares Inc & MBVT & 0.000 & & 0.742 & $* * *$ & 0.008 & \\
\hline Mercantile Bank Corp & MBWM & 0.000 & & 0.877 & $* * *$ & -0.006 & \\
\hline Macatawa Bank Corp & $\mathrm{MCBC}$ & 0.001 & & 0.621 & $* * *$ & -0.015 & \\
\hline MutualFirst Financial Inc & MFSF & -0.136 & $* * *$ & -1.648 & & 0.150 & \\
\hline Monarch Financial Holdings Inc & MNRK & -0.017 & $*$ & 1.214 & & 0.002 & \\
\hline MidWestOne Financial Group Inc & MOFG & 0.001 & & 0.801 & $* * *$ & -0.001 & \\
\hline MainSource Financial Group Inc & MSFG & 0.001 & & 0.952 & $* * *$ & -0.005 & \\
\hline MidSouth Bancorp Inc & MSL & -0.002 & $* *$ & 1.081 & $* * *$ & -0.023 & \\
\hline M \& T Bank Corp & MTB & 0.000 & & 1.039 & $* * *$ & -0.018 & $*$ \\
\hline National Bank Holdings Corp & NBHC & 0.000 & & 0.766 & $* * *$ & -0.033 & $* * *$ \\
\hline Northeast Bancorp & NBN & -0.245 & $* * *$ & 2.208 & & 0.247 & \\
\hline NBT Bancorp Inc & NBTB & 0.001 & & 0.987 & $* * *$ & -0.020 & $*$ \\
\hline National Bankshares Inc & NKSH & 0.000 & & 0.875 & $* * *$ & 0.000 & \\
\hline National Penn Bancshares Inc & NPBC & 0.000 & & 0.913 & $* * *$ & -0.020 & \\
\hline Northern Trust Corp & NTRS & 0.000 & & 1.199 & $* * *$ & -0.024 & $* *$ \\
\hline
\end{tabular}




\begin{tabular}{|c|c|c|c|c|c|c|c|}
\hline Firm & Ticker & $\boldsymbol{\alpha}_{\mathrm{i}}$ & & $\beta_{\mathrm{i}}$ & & $\gamma_{i}$ & \\
\hline Norwood Financial Corp & NWFL & -0.435 & $* * *$ & 2.624 & & 0.437 & \\
\hline OFG Bancorp & OFG & -0.001 & & 1.806 & $* * *$ & -0.036 & \\
\hline Southwest Bancorp Inc OK & OKSB & 0.000 & & 0.870 & $* * *$ & 0.005 & \\
\hline Old Line Bancshares & OLBK & -0.009 & & 0.265 & & 0.017 & \\
\hline Old National Bancorp & ONB & 0.000 & & 1.129 & $* * *$ & -0.030 & $* * *$ \\
\hline Old Point Financial Corp & OPOF & -0.273 & $* * *$ & -3.728 & & 0.296 & \\
\hline Oritani Financial Corp & ORIT & 0.000 & & 0.738 & $* * *$ & -0.020 & $*$ \\
\hline Orrstown Financial Services Inc & ORRF & -0.046 & $* * *$ & -1.832 & & 0.083 & \\
\hline Old Second Bancorp Inc & OSBC & 0.001 & & 0.656 & $* * *$ & -0.007 & \\
\hline Ohio Valley Banc Corp & OVBC & -0.546 & $* * *$ & -3.449 & & 0.568 & \\
\hline Bank of The Ozarks Inc & OZRK & 0.001 & & 1.346 & $* * *$ & -0.025 & $*$ \\
\hline PacWest Bancorp DE & PACW & 0.000 & & 1.330 & $* * *$ & -0.030 & $* * *$ \\
\hline Prosperity Bancshares Inc & PB & 0.000 & & 1.421 & $* * *$ & -0.036 & $* * *$ \\
\hline Porter Bancorp Inc & PBIB & -0.126 & $* * *$ & 1.859 & & 0.145 & \\
\hline Pacific Continental Corp & PCBK & 0.001 & & 0.903 & $* * *$ & -0.009 & \\
\hline Peoples Bancorp NC Inc & PEBK & -0.336 & $* * *$ & 4.829 & & 0.297 & \\
\hline Peoples Bancorp Inc & PEBO & 0.000 & & 0.913 & $* * *$ & -0.028 & $*$ \\
\hline Premier Financial Bancorp Inc & PFBI & 0.000 & & 0.375 & $* * *$ & -0.017 & \\
\hline Peoples Financial Corp MS & PFBX & -0.487 & $* * *$ & 7.742 & & 0.453 & \\
\hline Peapack Gladstone Financial Corp & PGC & 0.000 & & 0.820 & $* * *$ & -0.016 & \\
\hline Parke Bancorp Inc & PKBK & -0.162 & $* * *$ & 6.865 & $* *$ & 0.129 & \\
\hline Pacific Mercantile Bancorp & PMBC & -0.036 & $* * *$ & 2.768 & $*$ & 0.095 & \\
\hline PNC Financial Services Group Inc & PNC & 0.000 & & 1.062 & $* * *$ & -0.026 & $* * *$ \\
\hline Pinnacle Financial Partners Inc & PNFP & 0.001 & & 1.317 & $* * *$ & -0.025 & $* *$ \\
\hline Park Sterling Bank & PSTB & 0.000 & & 0.870 & $* * *$ & -0.012 & \\
\hline Privatebancorp Inc & PVTB & 0.001 & $*$ & 1.400 & $* * *$ & -0.030 & $* *$ \\
\hline Penns Woods Bancorp Inc & PWOD & 0.000 & & 0.733 & $* * *$ & 0.012 & \\
\hline Republic Bancorp Inc KY & RBCAA & 0.000 & & 0.978 & $* * *$ & -0.020 & \\
\hline Royal Bancshares PA Inc & RBPAA & -0.008 & & 0.898 & & 0.033 & \\
\hline Regions Financial Corp & $\mathrm{RF}$ & 0.000 & & 1.348 & $* * *$ & -0.034 & $* * *$ \\
\hline Sandy Spring Bancorp Inc & SASR & 0.001 & & 1.029 & $* * *$ & -0.015 & \\
\hline Seacoast Banking Corp FL & SBCF & 0.001 & $*$ & 0.913 & $* * *$ & -0.010 & \\
\hline S B Financial Group Inc & SBFG & -0.190 & $* * *$ & 5.197 & & 0.204 & \\
\hline Southside Bancshares Inc & SBSI & 0.000 & & 1.081 & $* * *$ & -0.026 & $*$ \\
\hline Southern First Bancshares Inc & SFST & -0.271 & $* * *$ & 0.634 & & 0.263 & \\
\hline Southwest Georgia Financial Corp & SGB & -0.671 & $* * *$ & -0.702 & & 0.708 & \\
\hline Shore Bancshares Inc & SHBI & -0.100 & $* * *$ & -0.860 & & 0.109 & \\
\hline SVB Financial Group & SIVB & 0.000 & & 1.770 & $* * *$ & -0.037 & $* *$ \\
\hline Sun Bancorp Inc NJ & SNBC & 0.009 & & 1.716 & $*$ & -0.017 & \\
\hline Synovus Financial Corp & SNV & 0.001 & & 1.212 & $* * *$ & -0.031 & $* * *$ \\
\hline Southern National Bancorp VA Inc & SONA & -0.109 & $* * *$ & 1.082 & & 0.110 & \\
\hline 1st Source Corp & SRCE & 0.000 & & 0.997 & $* * *$ & -0.014 & \\
\hline South State Corp & SSB & 0.000 & & 0.995 & $* * *$ & -0.017 & \\
\hline Stewardship Financial Corp & SSFN & -0.526 & $* * *$ & 10.382 & $* *$ & 0.463 & \\
\hline S \& T Bancorp Inc & STBA & 0.000 & & 1.018 & $* * *$ & -0.024 & $*$ \\
\hline State Bank Financial Corp & STBZ & 0.001 & & 0.935 & $* * *$ & -0.029 & $* *$ \\
\hline SunTrust Banks Inc & STI & 0.000 & & 1.233 & $* * *$ & -0.030 & $* * *$ \\
\hline State Street Corp & STT & 0.000 & & 1.318 & $* * *$ & -0.014 & \\
\hline Severn Bancorp Inc MD & SVBI & -0.307 & $* * *$ & 8.329 & $* *$ & 0.268 & \\
\hline Stock Yards Bancorp Inc & SYBT & 0.001 & & 1.009 & $* * *$ & 0.003 & \\
\hline Bancorp Inc & TBBK & -0.001 & & 1.365 & $* * *$ & -0.026 & \\
\hline TCF Financial Corp & TCB & 0.000 & & 1.306 & $* * *$ & -0.034 & $* * *$ \\
\hline Texas Capital Bancshares Inc & TCBI & 0.000 & & 1.494 & $* * *$ & -0.049 & $* * *$ \\
\hline Trico Bancshares & TCBK & 0.000 & & 0.849 & $* * *$ & -0.020 & $*$ \\
\hline Community Financial Corp MD & TCFC & -0.811 & $* * *$ & 5.301 & & 0.777 & \\
\hline First Financial Corp IN & THFF & 0.000 & & 0.848 & $* * *$ & -0.002 & \\
\hline Talmer Bancorp Inc & TLMR & 0.001 & & 0.679 & $* * *$ & -0.026 & $* *$ \\
\hline Two River Bancorp & TRCB & -0.282 & $* * *$ & 1.279 & & 0.271 & \\
\hline Trustmark Corp & TRMK & 0.000 & & 1.070 & $* * *$ & -0.029 & $* * *$ \\
\hline TrustCo Bank Corp NY & TRST & 0.000 & & 1.046 & $* * *$ & -0.016 & \\
\hline United Security Bankshares & UBFO & -0.145 & $* * *$ & -0.285 & & 0.146 & \\
\hline
\end{tabular}




\begin{tabular}{|c|c|c|c|c|c|c|c|}
\hline Firm & Ticker & $\boldsymbol{\alpha}_{\mathrm{i}}$ & & $\beta_{i}$ & & $\gamma_{i}$ & \\
\hline United Financial Bancorp Inc & UBNK & 0.000 & & 0.818 & $* * *$ & -0.006 & \\
\hline United Bancshares Inc & UBOH & -0.336 & $* * *$ & -5.296 & & 0.355 & \\
\hline Union Bankshares Corp & UBSH & 0.000 & & 0.970 & $* * *$ & -0.026 & $* *$ \\
\hline United Bankshares Inc & UBSI & 0.001 & & 1.045 & $* * *$ & -0.029 & $* *$ \\
\hline United Community Banks Inc GA & UCBI & 0.001 & & 1.142 & $* * *$ & -0.030 & $* *$ \\
\hline UMB Financial Corp & UMBF & 0.000 & & 1.175 & $* * *$ & -0.030 & $* *$ \\
\hline Umpqua Holdings Corp & UMPQ & 0.000 & & 1.168 & $* * *$ & -0.027 & $* *$ \\
\hline Union Bankshares Inc & UNB & -0.281 & $* * *$ & 1.118 & & 0.278 & \\
\hline Unity Bancorp Inc & UNTY & -0.181 & $* * *$ & -1.050 & & 0.181 & \\
\hline US Bancorp DE & USB & 0.000 & & 1.032 & $* * *$ & -0.021 & $* *$ \\
\hline Univest Corp of Pennsylvania & UVSP & 0.000 & & 0.782 & $* * *$ & 0.008 & \\
\hline Village Bank And Trust Financial Corp & VBFC & -0.813 & $* * *$ & -14.277 & $*$ & -1.165 & \\
\hline Western Alliance Bancorporation & WAL & 0.001 & $*$ & 1.367 & $* * *$ & -0.032 & $* *$ \\
\hline Washington Trust Bancorp Inc & WASH & 0.000 & & 0.906 & $* * *$ & -0.003 & \\
\hline Webster Financial Corp & WBS & 0.001 & & 1.262 & $* * *$ & -0.029 & $* *$ \\
\hline Washington First Bancshares Inc & WFBI & -0.427 & $* * *$ & -0.556 & & 0.429 & \\
\hline Wells Fargo \& Co & WFC & 0.000 & & 1.052 & $* * *$ & -0.032 & $* * *$ \\
\hline Wilshire Bancorp Inc & WIBC & 0.000 & & 1.165 & $* * *$ & -0.026 & $*$ \\
\hline WSFS Financial Corp & WSFS & -0.001 & & 1.035 & $* * *$ & -0.028 & \\
\hline WinTrust Financial Corporation & WTFC & 0.000 & & 1.081 & $* * *$ & -0.028 & $* * *$ \\
\hline Yadkin Financial Corp & YDKN & 0.001 & & 1.005 & $* * *$ & -0.028 & $* *$ \\
\hline Zions Bancorporation & ZION & 0.000 & & 1.424 & $* * *$ & -0.040 & $* * *$ \\
\hline \multicolumn{8}{|l|}{ Savings Banks } \\
\hline Anchor Bancorp WA & ANCB & -0.336 & $* * *$ & 3.162 & & 0.329 & \\
\hline Access National Corp & ANCX & 0.001 & & 0.584 & $* * *$ & -0.006 & \\
\hline ASB Bancorp Inc & ASBB & -0.549 & $* * *$ & 4.295 & & -1.464 & \\
\hline Bank Financial Corp & BFIN & 0.000 & & 0.724 & $* * *$ & -0.015 & \\
\hline Bancorp of New Jersey Inc & BKJ & -0.328 & $* * *$ & -5.274 & & 0.338 & \\
\hline BankUnited Inc & BKU & 0.000 & & 1.128 & $* * *$ & -0.029 & $* * *$ \\
\hline B of I Holding Inc & BOFI & -0.001 & & 1.158 & $* * *$ & -0.011 & \\
\hline Carver Bancorp Inc & CARV & -0.464 & $* * *$ & -6.301 & & 0.520 & \\
\hline Meta Financial Group Inc & CASH & 0.001 & & 0.768 & $* * *$ & -0.023 & \\
\hline Cape Bancorp Inc & CBNJ & 0.001 & & 0.181 & $* * *$ & -0.007 & \\
\hline Chicopee Bancorp Inc & CBNK & -0.354 & $* * *$ & -0.843 & & 0.390 & \\
\hline Capitol Federal Financial Inc & CFFN & 0.000 & & 0.688 & $* * *$ & -0.009 & \\
\hline Clifton Bancorp Inc & CSBK & 0.001 & & 0.438 & $* * *$ & -0.004 & \\
\hline Citizens Community Bancorp Inc MD & CZWI & -0.363 & $* * *$ & 5.321 & & 0.350 & \\
\hline ESSA Bancorp Inc & ESSA & 0.000 & & 0.119 & $* * *$ & 0.001 & \\
\hline Flagstar Bancorp Inc & $\mathrm{FBC}$ & 0.001 & & 0.948 & $* * *$ & -0.009 & \\
\hline 1st Constitution Bancorp & FCCY & -0.254 & $* * *$ & -2.440 & & 0.278 & \\
\hline First Clover Leaf Financial Corp & FCLF & -0.669 & $* * *$ & 2.204 & & -1.323 & \\
\hline First Defiance Financial Corp & FDEF & 0.001 & & 0.790 & $* * *$ & -0.015 & \\
\hline Flushing Financial Corp & FFIC & 0.000 & & 0.989 & $* * *$ & -0.011 & \\
\hline First Financial Northwest Inc & FFNW & 0.001 & & 0.385 & $* * *$ & -0.005 & \\
\hline First Niagara Financial Group Inc & FNFG & 0.001 & & 1.009 & $* * *$ & -0.032 & $* *$ \\
\hline First Savings Financial Group Inc & FSFG & -0.632 & $* * *$ & 0.472 & & 0.656 & \\
\hline Fox Chase Bancorp Inc & FXCB & 0.000 & & 0.394 & $* * *$ & -0.003 & \\
\hline Home Bancorp Inc & HBCP & -0.027 & $* *$ & -1.338 & & 0.032 & \\
\hline Hopfed Bancorp Inc & HFBC & -0.009 & & -0.202 & & 0.017 & \\
\hline Heritage Financial Corp WA & HFWA & 0.000 & & 0.776 & $* * *$ & -0.009 & \\
\hline HomeTrust Bancshares Inc & HTBI & 0.000 & & 0.470 & $* * *$ & -0.005 & \\
\hline Investors Bancorp Inc & ISBC & 0.000 & & 0.824 & $* * *$ & -0.017 & $* *$ \\
\hline MB Financial Inc & MBFI & 0.001 & & 1.204 & $* * *$ & -0.030 & $* *$ \\
\hline Mackinac Financial Corp & MFNC & -0.426 & $* * *$ & -3.868 & & 0.446 & \\
\hline Malvern Bancorp Inc & MLVF & -0.226 & $* * *$ & 3.528 & & 0.213 & \\
\hline Northfield Bancorp Inc DE & NFBK & 0.001 & & 0.568 & $* * *$ & -0.008 & \\
\hline Northrim Bancorp Inc & NRIM & 0.000 & & 0.657 & $* * *$ & -0.002 & \\
\hline Northwest Bancshares Inc & NWBI & 0.000 & & 0.730 & $* * *$ & -0.025 & $* * *$ \\
\hline NY Community Bancorp Inc & NYCB & 0.000 & & 0.870 & $* * *$ & -0.021 & $* *$ \\
\hline OceanFirst Financial Corp & OCFC & 0.000 & & 0.710 & $* * *$ & -0.021 & $*$ \\
\hline Ocean Shore Holding Co & OSHC & -0.045 & $* * *$ & 2.180 & & 0.026 & \\
\hline
\end{tabular}




\begin{tabular}{|c|c|c|c|c|c|c|c|}
\hline Firm & Ticker & $\alpha_{i}$ & & $\beta_{\mathrm{i}}$ & & $\gamma_{i}$ & \\
\hline Peoples United Financial Inc & PBCT & 0.000 & & 0.847 & $* * *$ & -0.024 & $* * *$ \\
\hline Prudential Bancorp Inc & PBIP & -0.054 & $* * *$ & -1.823 & & 0.075 & \\
\hline Provident Financial Services Inc & PFS & 0.001 & & 0.882 & $* * *$ & -0.017 & $*$ \\
\hline Pacific Premier Bancorp Inc & PPBI & 0.001 & $*$ & 0.765 & $* * *$ & -0.013 & \\
\hline Provident Financial Holdings Inc & PROV & 0.000 & & 0.269 & $* * *$ & 0.005 & \\
\hline Pulaski Financial Corp & PULB & 0.001 & & 0.348 & $* * *$ & -0.012 & \\
\hline Riverview Bancorp Inc & RVSB & -0.018 & $*$ & 1.169 & & 0.057 & \\
\hline SI Financial Group Inc MD & SIFI & -0.027 & $* *$ & -0.476 & & 0.024 & \\
\hline Southern Missouri Bancorp Inc & SMBC & -0.437 & $* * *$ & 1.466 & & 0.445 & \\
\hline Sterling Bancorp DE & STL & 0.001 & $*$ & 1.025 & $* * *$ & -0.018 & \\
\hline Territorial Bancorp Inc & TBNK & 0.001 & & 0.415 & $* * *$ & -0.008 & \\
\hline Timberland Bancorp Inc & TSBK & -0.181 & $* * *$ & 3.224 & & 0.168 & \\
\hline United Community Bancorp & UCBA & -0.444 & $* * *$ & 6.588 & & 0.390 & \\
\hline United Community Financial Corp Ohio & UCFC & 0.001 & & 0.920 & $* * *$ & -0.011 & \\
\hline Washington Federal Inc & WAFD & 0.000 & & 1.091 & $* * *$ & -0.024 & $* * *$ \\
\hline Westbury Bancorp Inc & WBB & -0.208 & & 3.405 & & 0.179 & \\
\hline \multicolumn{8}{|l|}{ Bank Holding Companies } \\
\hline Ameris Bancorp & $\mathrm{ABCB}$ & 0.001 & & 0.832 & $* * *$ & -0.014 & \\
\hline Astoria Financial Corp & $\mathrm{AF}$ & 0.001 & & 0.969 & $* * *$ & -0.019 & $*$ \\
\hline American River Bankshares & AMRB & -0.137 & $* * *$ & -5.257 & $*$ & 0.144 & \\
\hline Arrow Financial Corp & AROW & 0.000 & & 0.666 & $* * *$ & -0.027 & $* * *$ \\
\hline AmeriServ Financial Inc & ASRV & -0.027 & $* *$ & 1.259 & & 0.035 & \\
\hline Ames National Corp & ATLO & 0.000 & & 1.125 & $* * *$ & 0.001 & \\
\hline Auburn National Bancorp & AUBN & -0.472 & $* * *$ & 4.641 & & 0.446 & \\
\hline Bar Harbor Bankshares & BHB & 0.001 & & 0.713 & $* * *$ & 0.007 & \\
\hline Berkshire Hills Bancorp Inc & BHLB & 0.001 & & 0.852 & $* * *$ & -0.017 & $*$ \\
\hline Bryn Mawr Bank Corp & BMTC & 0.000 & & 0.727 & $* * *$ & -0.025 & $* *$ \\
\hline B N C Bancorp & $\mathrm{BNCN}$ & 0.001 & & 0.940 & $* * *$ & -0.011 & \\
\hline Boston Private Financial Holdings Inc & BPFH & 0.000 & & 1.142 & $* * *$ & -0.029 & $* *$ \\
\hline Brookline Bancorp Inc & BRKL & 0.001 & & 0.813 & $* * *$ & -0.020 & * \\
\hline First Busey Corp & BUSE & 0.005 & & 1.959 & $* * *$ & 0.003 & \\
\hline Baylake Corp & BYLK & -0.100 & $* * *$ & -0.018 & & 0.091 & \\
\hline Cascade Bancorp & $\mathrm{CACB}$ & 0.000 & & 0.864 & $* * *$ & 0.011 & \\
\hline California First National Bancor & CFNB & -0.568 & $* * *$ & 3.669 & & -1.445 & \\
\hline Cardinal Financial Corp & CFNL & 0.001 & & 1.025 & $* * *$ & -0.026 & $* *$ \\
\hline City Holding Co & $\mathrm{CHCO}$ & 0.000 & & 0.928 & $* * *$ & -0.022 & $*$ \\
\hline Charter Financial Corp & CHFN & 0.001 & & 0.458 & $* * *$ & -0.002 & \\
\hline Citizens Holding Co & CIZN & -0.494 & $* * *$ & -1.597 & & -1.497 & * \\
\hline Carolina Bank Holdings Inc & $\mathrm{CLBH}$ & -0.262 & $* * *$ & 0.174 & & 0.234 & \\
\hline CoBiz Financial Inc & COBZ & 0.001 & & 0.958 & $* * *$ & -0.021 & \\
\hline Community Trust Bancorp Inc & CTBI & 0.000 & & 0.735 & $* * *$ & -0.012 & \\
\hline Central Valley Community Bancorp & CVCY & -0.100 & $* * *$ & 4.673 & $*$ & 0.102 & \\
\hline Codorus Valley Bancorp Inc & CVLY & -0.318 & $* * *$ & -1.248 & & 0.322 & \\
\hline Community West Bancshares & CWBC & -0.436 & $* * *$ & -1.033 & & 0.447 & \\
\hline Citizens \& Northern Corp & $\mathrm{CZNC}$ & 0.000 & & 0.607 & $* * *$ & -0.008 & \\
\hline Dime Community Bancshares & DCOM & 0.000 & & 0.789 & $* * *$ & -0.019 & $*$ \\
\hline DNB Financial Corp & DNBF & -0.562 & $* * *$ & -1.863 & & 0.575 & \\
\hline Enterprise Bancorp Inc & EBTC & 0.001 & & 1.226 & $* * *$ & -0.009 & \\
\hline First Business Financial Services Inc & FBIZ & -0.001 & & 0.665 & $* * *$ & -0.008 & \\
\hline First Community Corp Sc & FCCO & -0.372 & $* * *$ & -3.778 & & 0.423 & \\
\hline First Interstate BancSystem Inc & FIBK & 0.000 & & 0.943 & $* * *$ & -0.026 & $* *$ \\
\hline Park National Corp & PRK & 0.001 & & 1.081 & $* * *$ & -0.016 & \\
\hline Renasant Corp & RNST & 0.001 & & 1.012 & $* * *$ & -0.014 & \\
\hline Salisbury Bancorp Inc & SAL & -0.482 & $* * *$ & -2.847 & & 0.499 & \\
\hline Sussex Bancorp & SBBX & -0.382 & $* * *$ & -2.881 & & 0.395 & \\
\hline Simmons 1st National Corp & SFNC & 0.001 & & 0.973 & $* * *$ & -0.028 & $* *$ \\
\hline Tompkins Financial Corp & TMP & 0.001 & & 1.006 & $* * *$ & -0.015 & \\
\hline United Security Bancshares Inc & USBI & -0.226 & $* * *$ & 3.619 & & 0.226 & \\
\hline Westamerica Bancorporation & WABC & 0.000 & & 1.051 & $* * *$ & -0.021 & * \\
\hline West Bancorporation Inc & WTBA & 0.001 & & 1.007 & $* * *$ & -0.015 & \\
\hline
\end{tabular}




\begin{tabular}{|c|c|c|c|c|c|c|c|}
\hline Firm & Ticker & $\boldsymbol{\alpha}_{\mathbf{i}}$ & & $\beta_{\mathbf{i}}$ & & $\gamma_{\mathbf{i}}$ & \\
\hline \multicolumn{8}{|c|}{ Investment Banks, Security Dealers/Brokers, Advisory Services } \\
\hline American National Bankshares Inc & AMNB & 0.001 & & 0.930 & $* * *$ & -0.003 & \\
\hline Goldman Sachs Group Inc & GS & 0.000 & & 1.232 & $* * *$ & -0.017 & * \\
\hline HomeStreet Inc & HMST & 0.001 & & 0.668 & $* * *$ & -0.027 & $*$ \\
\hline Morgan Stanley Dean Witter \& Co & MS & 0.000 & & 1.505 & $* * *$ & -0.022 & $* *$ \\
\hline Raymond James Financial Inc & RJF & 0.000 & & 1.258 & $* * *$ & -0.031 & $* * *$ \\
\hline Schwab Charles Corp & SCHW & 0.001 & & 1.537 & $* * *$ & -0.049 & $* * *$ \\
\hline Stifel Financial Corp & SF & -0.001 & & 1.489 & $* * *$ & -0.019 & \\
\hline WesBanco Inc & WSBC & 0.000 & & 0.944 & $* * *$ & -0.012 & \\
\hline \multicolumn{8}{|l|}{ Other Finance } \\
\hline American Express Co & AXP & -0.001 & & 0.739 & $* * *$ & -0.005 & \\
\hline Banner Corp & BANR & 0.000 & & 1.101 & $* * *$ & -0.030 & $* *$ \\
\hline Bank Mutual Corp & BKMU & 0.001 & & 0.946 & $* * *$ & -0.007 & \\
\hline B O K Financial Corp & BOKF & 0.000 & & 1.286 & $* * *$ & -0.025 & $* *$ \\
\hline Cass Information Systems Inc & CASS & 0.001 & & 1.147 & $* * *$ & -0.015 & \\
\hline Colony Bankcorp Inc & CBAN & -0.399 & $* * *$ & 0.911 & & 0.395 & \\
\hline Community Bank System Inc & $\mathrm{CBU}$ & 0.000 & & 1.021 & $* * *$ & -0.017 & \\
\hline Cullen Frost Bankers Inc & CFR & 0.000 & & 1.362 & $* * *$ & -0.026 & $*$ \\
\hline Cheviot Financial Corp & CHEV & -0.108 & $* * *$ & 1.335 & & 0.105 & \\
\hline CU Bancorp & CUNB & 0.000 & & 0.687 & $* * *$ & 0.003 & \\
\hline Emclaire Financial Corp & EMCF & -0.735 & $* * *$ & 4.381 & & 0.718 & \\
\hline E Trade Financial Corp & ETFC & 0.001 & & 1.590 & $* * *$ & -0.035 & $* *$ \\
\hline First American Financial Corp & FAF & 0.001 & & 0.894 & $* * *$ & 0.009 & \\
\hline First Marblehead Corp & FMD & 0.001 & & 1.519 & $* * *$ & 0.038 & \\
\hline Hilltop Holdings Inc & НTH & 0.000 & & 1.378 & $* * *$ & -0.024 & $*$ \\
\hline Marlin Business Services Corp & MRLN & 0.000 & & 1.167 & $* * *$ & 0.006 & \\
\hline Oak Valley Bancorp & OVLY & -0.564 & $* * *$ & 6.630 & & 0.517 & \\
\hline Plumas Bancorp & PLBC & -0.491 & $* * *$ & -9.821 & $* *$ & 0.554 & \\
\hline QCR Holdings Inc & QCRH & -0.008 & & 0.010 & & -0.001 & \\
\hline Tristate Capital Holdings Inc & TSC & 0.000 & & 0.944 & $* * *$ & -0.021 & \\
\hline Valley National Bancorp & VLY & 0.000 & & 0.988 & $* * *$ & -0.018 & $* *$ \\
\hline \multicolumn{8}{|l|}{ Joint test for all firms } \\
\hline $\mathrm{H} 1: \gamma_{1}=\gamma_{2}=\ldots=\gamma_{n}=0$ & & & & & & 837.83 & $* * *$ \\
\hline \multicolumn{8}{|l|}{ Joint test for all firms } \\
\hline $\mathrm{H} 2: \gamma_{1}=\gamma_{2}=\ldots=\gamma_{n}$ & & & & & & 837.70 & $* * *$ \\
\hline
\end{tabular}

In this table, we present the abnormal returns to each firm to the Fed's announcement that they were not increasing interest rates on September 17, 2015 estimated using Equation (1) as follows: $R_{i, t}=\alpha_{i}+\beta_{i} R_{M, t}+\gamma_{i} D_{t}+e_{i, t}$. where $R_{i, t}$ is the return of the stock on the $i^{t h}$ day, $R_{M, t}$ is the return on the Equally-Weighted CRSP Index on day $t$, and $D_{t}$ is a dummy variable taking the value of 1 on the event day (September 17, 2015) and 0 otherwise. We calculate daily returns using security prices obtained from CRSP for the period of June 30, 2014 through March 31, 2016. We classify firms into industry subsectors according to their NAICS code, obtained from CRSP. Significance is denoted by ***,**, and * at the $1 \%, 5 \%$, and $10 \%$ levels, respectively. 